\title{
A Brief Review of Anaerobic Digestion of Algae for Bioenergy
}

\author{
John J. Milledge *(D), Birthe V. Nielsen, Supattra Maneein and Patricia J. Harvey \\ Faculty of Engineering and Science, Algae Biotechnology Research Group, University of Greenwich, \\ Central Avenue, Chatham Maritime, Kent ME4 4TB, UK; B.V.Nielsen@greenwich.ac.uk (B.V.N.); \\ s.maneein@gre.ac.uk (S.M.); P.J.Harvey@greenwich.ac.uk (P.J.H.) \\ * Correspondence: j.j.milledge@gre.ac.uk; Tel.: +44-208-331-8871
}

Received: 7 March 2019; Accepted: 23 March 2019; Published: 26 March 2019 updates

\begin{abstract}
The potential of algal biomass as a source of liquid and gaseous biofuels has been the subject of considerable research over the past few decades, with researchers strongly agreeing that algae have the potential of becoming a viable aquatic energy crop with a higher energy potential compared to that from either terrestrial biomass or municipal solid waste. However, neither microalgae nor seaweed are currently cultivated solely for energy purposes due to the high costs of harvesting, concentrating and drying. Anaerobic digestion of algal biomass could theoretically reduce costs associated with drying wet biomass before processing, but practical yields of biogas from digestion of many algae are substantially below the theoretical maximum. New processing methods are needed to reduce costs and increase the net energy balance. This review examines the biochemical and structural properties of seaweeds and of microalgal biomass that has been produced as part of the treatment of wastewater, and discusses some of the significant hurdles and recent initiatives for producing biogas from their anaerobic digestion.
\end{abstract}

Keywords: macroalgae; microalgae; seaweed; biogas; methane; anaerobic digestion

\section{Introduction}

There has been significant research interest over the past 50 years in the use of algae as a source of biofuels due to the high potential biomass yield of algae and cultivation systems that do not compete for land or fresh water with terrestrial crops [1,2]. However, despite their clear potential and considerable research, there are no commercial-scale quantities of economically-viable fuel from either micro or macroalgae [3]. The dilute concentrations of microalgae in their growth medium and the high-water content (80-90\%) of algae impact adversely on the energy balance of processes that depend on dry biomass [4-7]. One of the critical challenges in achieving an energy return from microalgae is harvesting and concentrating the algae [8-10]. This is because of several factors including the small size of microalgae $(<30 \mu \mathrm{m})$ [11]; the dilute nature of the microalgal suspension $(0.02-0.05 \%$ dry solids) [12,13]; the small differences in density of the algal cells relative to that of the growth media [14]; and the negative charge on the surface of algal cells that results in dispersed long-lasting algal suspensions [15-17]. Drying the harvested biomass is also a highly energetic process and can use the equivalent of the vast majority of potential energy in the biomass $[18,19]$. Algae are thus unattractive for direct combustion, pyrolysis and gasification that require dry biomass due to the high-energy inputs for moisture removal, but suitable for processes that use wet biomass [20-22].

Anaerobic digestion (AD) consists of a series of actions by various groups of bacteria that convert organic materials into methane, carbon dioxide, and bacterial biomass (Figure 1). The biogas produced from the AD of seaweed typically contains methane $50-70 \%$, carbon dioxide $30-45 \%$, hydrogen $<2 \%$ and hydrogen sulphide $<3.5 \%$ [23-25]. AD is largely the method of choice for biomass with high 
water content, such as seaweed; it readily tolerates biomass with high moisture content without the energy drawbacks from dewatering and drying [26,27]. It is a relatively simple procedure from an infrastructure/engineering perspective. $\mathrm{AD}$ also has the capacity to utilise all the organic carbon material of algae rather than one specific component such as the production of biodiesel (fatty acid methyl ester, FAME) from lipids via transesterification, hence biogas systems tend to yield more energy from crops per hectare than liquid biofuel systems [28]. The majority of researchers evaluating the suitability of seaweed for AD from the 1970s through to the present mostly found that they were largely an appropriate biomass for AD [29]. Seaweed-derived biogas was used industrially in the 19th century, and more recently Tokyo Gas showed that $20 \mathrm{~m}^{3}$ of methane could be produced from one tonne of seaweed [30]. Currently, biofuel from seaweed AD is perhaps the closest to industrial exploitation [5,31]. Allen, et al. [28] have estimated that gross energy yields from the cultivation and $\mathrm{AD}$ of Saccharina latissima, at $186 \mathrm{GJ} \cdot \mathrm{ha}^{-1} \cdot \mathrm{yr}^{-1}$, were higher than those based on the current liquid biofuel systems such as ethanol from sugarcane (135 GJ.ha $\left.{ }^{-1} \cdot \mathrm{yr}^{-1}\right)$ and biodiesel from palm oil $\left(120 \mathrm{GJ} \cdot \mathrm{ha}^{-1} \cdot \mathrm{yr}^{-1}\right)$. Energy return on energy investment (EROI) is a 'simple' ratio of energy generated relative to the quantity of energy used in its production. This relationship can be valuable in assessing the feasibility of fuels. A ratio of $<1$ shows that more energy is expended than generated, and an EROI of 3 has been proposed as the minimum that can be considered sustainable [32]. EROI for crude oil is currently $\sim 20$ but has reduced over time [33]. The EROIs for biofuels made from biomass are frequently substantially less, with ethanol from sugar having an EROI between 1.25-8 and ethanol from corn 1-1.34 [32,34-37]. Methods that use the whole biomass instead of just the fermentable compounds have higher EROIs [38] with seaweed biogas giving an EROI of 2.4 and combined production of bioethanol and biogas from seaweed giving an EROI of 3.0 [39,40]. Pechsiri et al. [41]) also found an EROI of up to 2.6 for combined biogas and fertiliser production from large-scale cultivation of seaweed.

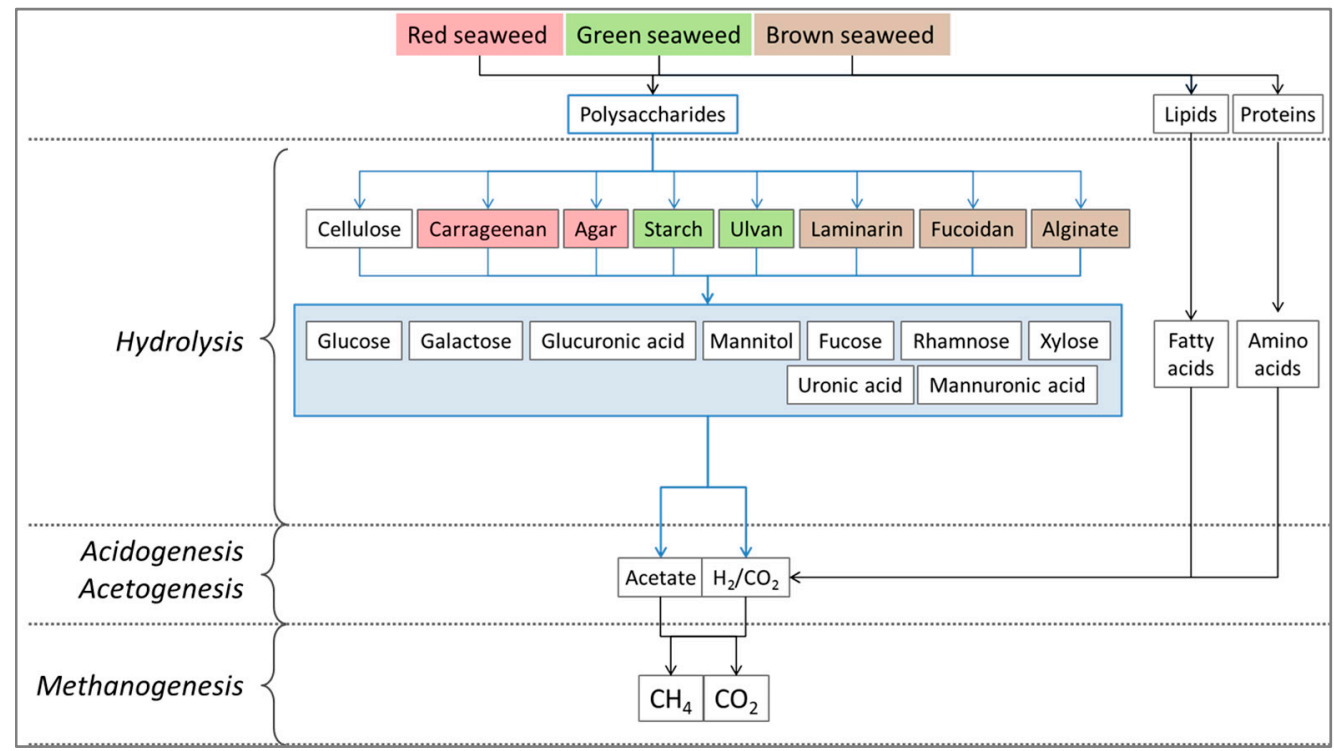

Figure 1. Major steps for biogas production. Cellulose, lipids, and proteins are generally found in all seaweeds. Laminarin, fucoidan, and alginate are typical of brown seaweed (colour-coded brown). Starch and ulvan are typical of green seaweeds (colour-coded green), and the polymeric polysaccharides carrageenan and agar are characteristic of red seaweeds (colour-coded red) [42].

Although the macroalgal industry currently produces 100 fold more wet biomass than the microalgal industry [43-45], much of the research on algal biofuels has been focused on micro- rather than macroalgae [46]. This has largely arisen because of the potential to select or develop microalgal strains with a high triacylglyceride (TAG) content suitable for transesterification to biodiesel $[4,47,48]$. Many LCAs have been performed on the production of biodiesel from microalgae. Algal biodiesel was 
found to be comparable to first-generation biodiesel only in the best-case scenarios, and biodiesel from microalgae was not, "really competitive under current feasibility assumptions" [49]. A "meta-model" of algae bio-energy life cycles revising data from six LCAs found EROIs that ranged between $<1$ to 2 [50]. Another review of LCA data using a Monte Carlo-based approach found that almost half of all prospective algal biodiesel processes had an EROI of less than 1 [6]. The study by Sills' [6] also demonstrated that methane from $\mathrm{AD}$ of algae residues after lipid removal is required for net gains in energy, and $\mathrm{AD}$ is a vital part of algal biodiesel processes with an EROI > 1. Also, nutrients recovered from waste streams are crucial. The embodied energy of nutrients is one of the primary energy inputs in biofuel production from microalgae [51].

Ter Veld [52] found an EORI $>3$ for biogas produced from microalgal biomass grown in high rate algal ponds (HRAPs) and concluded that microalgae-based biofuel sustainability was not set by areal productivity or lipid content in the algae but by the recovery of nutrients. Another energy balance model for the production of biogas from microalgae grown on wastewater found energy returns on operational energy invested greater than 3 with the use of nutrients from wastewater being a crucial component in producing a positive net energy balance [53,54]. It is also critical to minimise fresh water use in microalgal biofuel production not merely to minimise cost but also to circumvent a future problem with 'water versus fuel'. The use of wastewater or seawater for microalgal biofuel production can reduce the freshwater demand by $90 \%$ [55]. Park et al. [56] have concluded that HRAPs treating wastewater are currently the only economic means of producing microalgal biofuel with minimum environmental impact. This review will thus examine biogas from algal feedstocks grown in processes that minimise the demand for fresh water and nutrients; microalgae produced as part of the treatment of wastewater and seaweed cultivated or collected after growing in the ocean.

\section{Microalgal Wastewater Treatment for Biogas Production}

Microalgae play an important role in wastewater treatment in facultative (waste stabilisation) ponds where their capacity to oxygenate water is considered to be the most energy efficient and economical method available $[57,58]$. Mechanical aeration can, by contrast, be energy-intensive (0.4-1.1 kWh $1 \mathrm{~kg}^{-1} \mathrm{O}_{2}$ ) [59]. Facultative ponds are shallow human-made ponds where the organic component of the effluent is converted to microalgal and bacterial biomass in microalgal-bacterial flocs (MaB-flocs) with a continuous exchange of $\mathrm{O}_{2}$ and $\mathrm{CO}_{2}$ between microalgae and reduction of odours and pathogenic microorganisms [59-62]. Microalgae require nitrogen (N) and phosphorus (P) and are highly efficient at removing both elements from municipal wastewater that can have typical concentrations of $30-40 \mathrm{mg} \cdot \mathrm{L}^{-1} \mathrm{~N}$ and $5-10 \mathrm{mg} \cdot \mathrm{L}^{-1} \mathrm{P}$ [63]. Parachlorella kessleri-I removed $81 \%$ of the total $\mathrm{N}$ and $98 \%$ of the $\mathrm{P}$ from the water from Neela Hauz Lake (India) polluted by sewage [64].

Algal waste-stabilisation ponds ( 1 to $3 \mathrm{~m}$ deep) have become increasingly sophisticated as evidenced by the so-called "High Rate Algal Pond" (HRAP) [61,65]. A HRAP is a shallow closed-loop recirculation channel in which medium for the growth of algae flows around a central spine [66,67]. The raceway either can be a single loop or may be serpentine [56]. HRAP wastewater treatment systems can have reduced energy inputs relative to conventional treatments with $<0.6 \mathrm{kWh} \cdot \mathrm{kg}^{-1} \mathrm{BOD}$ removed compared with $0.8-6.4 \mathrm{kWh} \cdot \mathrm{kg}^{-1}$ BOD removed in mechanical aerated ponds $[59,68,69]$.

The depth of raceways for algal growth is a compromise between being adequately shallow to give plenty of light for the growth of algal cells, and sufficiently deep for fluid to be moved around the raceway without costly grading of the base of the pond [70]. Raceways may be up to $0.5 \mathrm{~m}$ deep [71], but are typically $0.2-0.3 \mathrm{~m}$ deep [44,72-74]. At less than $0.15 \mathrm{~m}$, problems can occur with algal sedimentation and in achieving a uniform grading of the pond bottom to get even flow around the whole raceway [75]. Problems with mixing, temperature variation and excessive rates of carbon dioxide outgassing may also occur at depths $<0.25 \mathrm{~m}$ [44].

Adequate mixing is needed to expose all cells to light, prevent settlement, enhance gaseous transfer and distribute nutrients $[57,63,76]$. The circulation requirement is normally provided by simple mechanical paddlewheels as they are high volume, low head devices with a gentle mixing 
action [77]. Flow velocities are typically 0.15 to $0.3 \mathrm{~m} \cdot \mathrm{s}^{-1}$ [77,78]. Oswald [57] recommended that the average velocity within a raceway should be $0.15 \mathrm{~m} \cdot \mathrm{s}^{-1}$ to maintain a minimum velocity $>0.05 \mathrm{~m} \cdot \mathrm{s}^{-1}$ around the whole raceway to keep the algae in suspension and prevent thermal stratification. Optimal mixing in algal ponds was found to occur at a flow rate of $0.2-0.3 \mathrm{~m} \cdot \mathrm{s}^{-1}$ [44], while a CFD model showed no increase in the growth of algae above $0.3 \mathrm{~m} \cdot \mathrm{s}^{-1}$ [66].

In addition to raceway depth and fluid flow velocity, the organic loading rate and hydraulic retention are the key operational factors in HRAPs treating wastewater [79]. In HRAPs the maximum organic loading rate is between $100-150 \mathrm{~kg} \mathrm{BOD}_{5} \mathrm{ha}^{-1}$. day ${ }^{-1}$ depending on climate [79]. The hydraulic retention time in temperate climates is 7-9 days in winter, and 3-4 days in summer [79].

Some species of algae can thrive in many wastewaters, but others do not perform well in wastewater depending on the source and type of waste [64]. Scenedesmus and Chlorella have both been shown to grow in a broad range of wastewaters [80]. Nevertheless, a single-species approach to large-scale algal cultivation on wastewater is challenging, and a community of several algal and bacterial species growing in a consortium offers the prospect of both system stability and increased yields [81-83]. Mixed species growth systems have been shown to improve biomass yield relative to algal monocultures grown under the same resource supply conditions, and open ponds potentially could utilise more nutrients (pollutants) than growing a single species [84,85]. Open systems remain the dominant algal technology at commercial scale for treating wastewater despite minimal control over the algal species, with only optimisation of pond operational factors such as residence time, depth and mixing.

Advanced Integrated Wastewater Pond System (AIWPS) or Integrated Algae Pond Systems (IAPS) integrate HRAPs with anaerobic and aerobic biological processes for wastewater treatment. Wastewater initially enters a covered anaerobic pond or advanced facultative pond where organic solids settle and decompose anaerobically producing biogas that is collected by a pond-cover for use as fuel $[56,79,86]$. Water laden with nutrients then flows to HRAPs where microalgae grow. The algal biomass produced in HRAP is used as feedstock for $\mathrm{AD}$ and, additionally, nutrients from the digestate from $\mathrm{AD}$ of the harvested algal biomass can be supplied to microalgal growth systems to stimulate algal growth further [87].

The construction capital costs for an Advanced Pond System are $<50 \%$, and operational costs are $<20 \%$ relative to activated sludge systems but require $\sim 50$-fold the land area of activated sludge systems for the same Biological Oxygen Demand (BOD) removal, excluding the land area needed to dispose of waste activated sludge [56]. Where land constraints permit AIWPS and IAPS are now utilised globally for the remediation of wastewater [68,79,86,88-90].

Bacteria and microalgae growing in waste stabilisation ponds utilise dissolved nutrients reducing BOD and yield substantial quantities of bacterial and microalgal biomass, which, if harvested, may serve as a source of organic material for feed and fuel [60]. On the other hand, Greenhouse Gas Emissions from facultative ponds in the form of $\mathrm{CH}_{4}$ emissions, although highly variable, are always positive [91], and can be captured for use as fuel. 'All-Gas' was an EU-funded project based on a 10-ha facility in Chiclana de la Frontera (Spain). All-Gas demonstrated on a semi-industrial scale the feasibility of the sustainable production of algal biogas for vehicle fuels, based on low-cost microalgae cultures grown in municipal wastewater. The four raceways, each with an area of $5200 \mathrm{~m}^{2}$, produced an average of 100 tonnes $\mathrm{ha}^{-1} \cdot \mathrm{yr}^{-1}$ of biomass; the annually produced biomethane from the conversion of the algae biomass grown in a hectare of raceway treating wastewater capable of powering 20 cars for $\sim 18,000 \mathrm{~km}$ each [92]. A Lifecycle assessment (LCA) of the algae biorefinery process gave greenhouse gas reductions of $\sim 40 \%$ relative to conventional wastewater treatment, with the chief benefit (credit) resulting from the substitution of the Compressed Natural Gas for automotive fuel by biomethane [93].

\section{Seaweed}

Technically all seaweeds can be converted into biomethane, but potential biomass yield should be carefully considered before selecting a species for commercial biofuel production as should the 
environmental impact of large-scale harvesting of natural seaweed. Currently, the vast majority of seaweed is cultivated or naturally harvested for either human consumption or pharmaceutical (hydrocolloids) applications, Table 1. Benzie and Hynes [94] have suggested that near-shore, longline cultivation of seaweed could have a productivity 15-45 tons of dry biomass per hectare per year and give scope for minimising the production of conventional fuel crops such as corn and soybean.

Table 1. Cultivated seaweed, production and industry [95].

\begin{tabular}{|c|c|c|c|c|}
\hline Species & Location & $\begin{array}{l}\text { Production (Wet Tonnes) } \\
2014-2009 \text { (\% Increase) }\end{array}$ & Industry & Harvesting \\
\hline Eucheuma spp & $\begin{array}{l}\text { China, Philippines, United Rep. of } \\
\text { Tanzania, Kiribati, Indonesia, } \\
\text { Malaysia, Solomon Islands and } \\
\text { Fiji Islands }\end{array}$ & $\begin{array}{l}9,053,044(2014) \\
2,875,547(2009) \\
315 \%\end{array}$ & $\begin{array}{l}\text { Carrageenan } \\
\text { production }\end{array}$ & 10-12 weeks \\
\hline Laminaria japonica & $\begin{array}{l}\text { China, Japan, the RO Korea and } \\
\text { the Democratic People's Republic } \\
\text { of Korea. }\end{array}$ & $\begin{array}{l}7,654,586(2014) \\
4,930,705(2009) \\
155 \%\end{array}$ & $\begin{array}{l}\text { Algin, mannitol, } \\
\text { and iodine }\end{array}$ & 8 months \\
\hline Porphyra spp & China, RO Korea, and Japan & $\begin{array}{l}1,141,710(2014) \\
1,074,750(2009) \\
106 \%\end{array}$ & Food (Nori) & $\begin{array}{l}10 \text { days to } \\
5 \text { months }\end{array}$ \\
\hline Gracilaria spp & $\begin{array}{l}\text { Asia (Indonesia, Korea } \\
\text { Philippines, Vietnam China, } \\
\text { Taiwan), Africa (Namibia and } \\
\text { South Africa), America } \\
\text { (Argentina, Brazil, Chile } \\
\text { and Peru), }\end{array}$ & $\begin{array}{l}3,751,395(2014) \\
1,526,393(2009) \\
246 \%\end{array}$ & Agar & 30-45 days \\
\hline Undaria pinnatifida & $\begin{array}{l}\text { China, RO Korea, and Japan } \\
\text { Small scale cultivation French } \\
\text { Brittany coast and the Spanish } \\
\text { Galician coast, }\end{array}$ & $\begin{array}{l}2,358,597(2014) \\
1,694,540(2009) \\
139 \%\end{array}$ & Food (Wakame) & Yearly \\
\hline
\end{tabular}

Cast seaweed is usually collected 2-3 times a year, hence suitable storage of biomass is needed [96]. Herrmann, et al. [97] suggested ensiling to prevent decomposition of wet biomass with comparatively low energy input. During ensiling soluble carbohydrates in an anaerobic environment are converted to organic acids, primarily lactic acid. The authors conclude that the collection and use of effluent is imperative to avoid methane losses.

Several studies have assessed the potential of converting seaweed into biogas, and a few pilot studies have also been described. For example, Ulva lactuca has been cultivated successfully for biomass production and bioremediation of wastewater [98]. Pilot studies indicated that the yearly yield of Ulva lactuca is $4-5$ times greater than terrestrial energy crops with a methane yield at a level between cow manure and energy crops $[99,100]$. Though the analysis of the ash indicates the potential for high-value fertiliser, the authors conclude that production of Ulva solely for energy is still too costly and that new production methods are required to reduce costs or an integrated biorefinery approach is needed in order to extract high-value products before use for energy.

\section{Seaweed Biogas}

Energy crops (aquatic and terrestrial) for methane production is a widely researched area, and energy potential of marine biomass is estimated above $100 \mathrm{EJ} \mathrm{yr}^{-1}$, considerably greater than

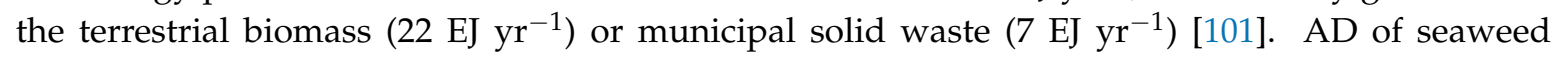
has been reported to result in a wide range of biomethane yields caused by variation in species and seasonal chemical composition of the biomass, with brown algae AD methane yields generally larger than those from green algae [29]. Despite variability in reported biomethane potentials (BMPs, defined as the maximum volume of $\mathrm{CH}_{4}$ produced per $\mathrm{g}$ of volatile solids (VS) established in batch laboratory tests [102]), research in this area strongly agrees that macroalgae have the potential of becoming an economically viable aquatic energy crop when considered in the context of the circular economy. For example, COASTAL Biogas, an Interreg South Baltic project co-financed by the European Regional Development Fund focuses on the removal of nutrients from the Baltic Sea by collecting 
cast seaweed to counteract eutrophication. The collected seaweed will be used as co-substrate in anaerobic digestion and the digestate as a bio-fertiliser. A review from HELCOM [103] shows that the Baltic Sea is still profoundly affected by eutrophication which impacts on marine organisms and vegetation. One symptom of eutrophication is the proliferation of opportunistic, fast-growing seaweeds [104]. Eutrophic conditions can increase biomass yield from seaweed farming, although damaging seaweed epiphytes growth can also be stimulated [105]. Beside reducing nutrients load, the collection, and possible cultivation, of seaweeds is likely to mitigate this eutrophication and have other socio-economic benefits. A study of the sustainable use of seaweed for biogas production in the Latvian Baltic region found the collection of natural seaweed from the Baltic had a significant benefit in reducing eutrophication and was a "sustainable and feasible scenario" [106]. However, it was concluded that 'sensitive management' was required to prevent considerable damage to the local Baltic ecosystem [106]. Similarly, integrated biorefineries such as Macrocascade launched in 2016 (https://www.bbi-europe.eu/projects/macrocascade) are now being established to prove the concept of the cascading marine macroalgal biorefinery. Macrocascade is a production platform that covers the entire technological chain for processing sustainably cultivated seaweed into highly processed value-added products. Depending on seaweed types and species, products such as fatty acids, oils, natural pigments, antioxidants, and high-value biological components can be extracted with organic 'leftovers' aimed for biomethane production [107]. Mhatre et al. [108] explored the BMP after extraction of potential AD inhibitors ('sap', protein and ulvan) and reported an increased methane output of $408 \mathrm{~mL} \mathrm{CH}_{4} \mathrm{~g}^{-1} \mathrm{VS}$ (70.9\% of maximum theoretical) observed in the residue where 'sap' (a mineral-rich extract) and ulvan had been removed compared to $211 \mathrm{~mL} \mathrm{CH}_{4} \mathrm{~g}^{-1} \mathrm{VS}$ for the untreated biomass. Tedesco and Daniels [109] also concluded that the residues from seaweed following solvent extraction are more suitable for biogas production than fresh or drift seaweed substrates alone. However, for a viable biorefinery approach to work, barriers such as limited technologies and the variable amount and quality of seaweed must be broken.

In Ireland, about 30,000 wet tonnes of cast seaweed are collected each year in what is termed 'wild harvest'. A recent techno-economic assessment of seaweed feedstock for AD found that for seaweed combined with food waste, cattle slurry and grass a financial incentive of between 0.85 and $1.17 € \cdot \mathrm{m}^{-3}$ was needed for viability, compared to the wholesale methane sales price of $0.2 € \cdot \mathrm{m}^{-3}$ [110]. The reported BMP yield for cast brown seaweed was $342 \mathrm{~L} \mathrm{CH}_{4} \mathrm{~kg}^{-1} \mathrm{VS}$ for Saccharina latissimi and $166 \mathrm{~L} \mathrm{CH}_{4} \mathrm{~kg}^{-1} \mathrm{VS} \mathrm{A}$. nodosum [28]. Sustainability is expected to increase with concepts such as BioEnergy with Carbon Capture and Storage (BECCS) [111]. Microalgae cultivation with the removal of $\mathrm{CO}_{2}$ from biomethane as described by Xia et al. [96] may be another alternative method of sustainable carbon capture.

\section{Challenges to Biogas Production from Macro- and Microalgae}

One of the key factors in achieving a positive energy balance in algal AD is a high conversion of organic material to methane; increasing $\mathrm{CH}_{4}$ yield from $\mathrm{AD}$ of seaweed was found to be a vital factor in improving process energy balance and reducing greenhouse gas emissions $[41,53,112]$. Real-world yields of biogas from digestion of many algae are substantially below the theoretical maximum. Seaweed typical methane yields ( 200 $\mathrm{L} \mathrm{CH}_{4} \mathrm{~g}^{-1} \mathrm{VS}$ ) $[38,43]$ are less than $50 \%$ of that from common commercially exploited feedstocks [113-117]. The methane potential of Sargassum muticum, a brown seaweed, for example, is only $\sim 0.13 \mathrm{~L} \mathrm{CH}_{4} \mathrm{~g}^{-1} \mathrm{VS}$, and amount to less than $27 \%$ of theoretical maximum methane yield [118-120]. However, there is considerable variability between species of seaweed in their 'anaerobic digestibility' with methane potential varying between $19-81 \%$ of theoretical [28]. On the other hand, mixed microalgal species biomass produced in HRAP treating wastewater can have yields of up to $88 \%$ of the theoretical methane potential $[90,121]$. Microalgal biomass produced in a HRAP treating wastewater in Barcelona, Spain had a methane yield $~ 50 \%$ of the theoretical [122] However, the methane yield from microalgae can vary widely from 0.024 to $0.6 \mathrm{~L} \mathrm{CH}_{4} \mathrm{~g}^{-1}$ VS depending on species and conditions $[90,121]$. Then again, the reported methane yield for the same species can 
vary significantly, for example, the methane yield from the AD of Dunaliella has been reported as $0.063 \mathrm{~L} \mathrm{CH}_{4} \mathrm{~g}^{-1}$ VS [123] and $0.323 \mathrm{~L} \mathrm{CH}_{4} \mathrm{~g}^{-1}$ VS [124].

There is extensive discussion about the explanations for the low methane yield from many species of algae. Suggested potential causes of the recalcitrance of algae in AD are: a) structure and cell wall structure, b) polysaccharides that are not readily hydrolysed, c) polyphenols, d) organic sulphur compounds, e) other antimicrobial and toxins, f) C:N ratio and g) heavy metals $[26,125]$.

The bacteria concerned in the production of methane by AD are sensitive to the chemical make-up of the feedstock $[56,126,127]$. There are considerable differences in the composition and compounds found in algae and indeed considerable differences between algae types and species [23].

\subsection{Algal Composition}

The relative quantities of carbohydrates, proteins and lipids in algae affect the methane production potential of algae [128]. Lipids yield greater volumes of biogas per gram of organic matter than either carbohydrate or protein $[12,129,130]$. At the same time algal composition varies widely depending on species, season and environmental conditions, and in the case of seaweed, thallus segment (holdfast, stipe, etc.), which poses a challenge for reproducibility in biomethane generation [23,131-134]. Also, the bacteria associated with the production of methane by AD are sensitive to the chemical composition of the feedstock $[56,126,127]$. The lipid, protein and carbohydrate composition of a number of seaweeds is shown in Table 2 and for microalgae in Table 3.

Table 2. Lipid, protein and carbohydrate composition of various seaweeds \% dw [135].

\begin{tabular}{llll}
\hline Algae & Lipids & Proteins & Carbohydrates \\
\hline Green algae & & & \\
Codium fragile & 1.8 & 10.9 & 32.3 \\
$\begin{array}{l}\text { Enteromorpha linza } \\
\text { Ulva Lactuca }\end{array}$ & 1.8 & 31.6 & 37.4 \\
Red algae & 6.2 & 20.6 & 54.3 \\
Gelidium amansii & & & \\
Porphyra tenera & $0-3.1$ & $15.6-16.3$ & $61-67.3$ \\
Gracilaria verrucosa & 4.4 & 38.7 & 35.9 \\
Brown algae & 3.2 & 15.6 & 33.5 \\
Laminaria japonica & & & \\
Hizikia fusiforme & $1.8-2.4$ & $9.4-14.8$ & $51.9-59.7$ \\
Saccharina japonica & $0.4-1.5$ & $5.9-13.9$ & $28.6-59$ \\
Sargassum fulvellum & 0.5 & 19.9 & 44.5 \\
Ecklonia stolonifera & 1.6 & 10.6 & 66 \\
Unduria pinnatifida & 2.4 & 13.6 & 48.6 \\
Sargassum fulvelum & $1.8-2.0$ & $15.9-18.3$ & $40.1-52$ \\
\hline
\end{tabular}

The low lipid content of macroalgae has been suggested makes them 'especially suitable' for biogas production via AD [21,136]. Microalgae, unlike seaweed, can be rich in lipids with levels of 20 to $50 \%$ being common, and in some case $>70 \%$ when 'stressed' during growth $[67,137,138]$. This high lipid content led to extensive research into the large-scale cultivation of microalgae for fuel production especially biodiesel since World War II $[4,6,47,67,132,139,140]$. Triglycerides and long chain fatty acids (LCFAs) have a high methane potential, but they can be problematic for $\mathrm{AD}$ when present in high concentrations causing process blockages, recalcitrant floating fatty crusts and LCFAs adhering to the surface of acetoclastic and methanogenic bacteria and inhibiting their growth [141-143]. Palmitic (C16:0), stearic (C16:0) and oleic acid (C18:1) at high concentrations $\left(>3 \mathrm{~g} \cdot \mathrm{L}^{-1}\right)$ caused a $>50 \%$ reduction in methane production [144]. LCFAs are broken down via $\beta$-oxidation degradation pathway to acetate and hydrogen and subsequently to methane; saturated LCFAs can enter the pathway directly, but the exact pathway for unsaturated LCFA is unclear, although they may need to be saturated as a 
first step [142,143]. Interestingly, although biogas production was not affected, a positive correlation between lipid removal and seaweed degradation was discovered during rumen fermentation [145].

Table 3. Lipid, protein and carbohydrate composition of various microalgae \% dw [146].

\begin{tabular}{llll}
\hline Algae & Lipid & Protein & Carbohydrate \\
\hline Spirulina platensis & $4-9$ & $50-65$ & $8-14$ \\
Chlorella sp. & $14-22$ & $51-58$ & $12-17$ \\
Scenedesmus sp. & $12-14$ & $50-56$ & $10-52$ \\
Dunaliella sp. & $6-8$ & $49-57$ & $4-32$ \\
Synechococcus sp. & 11 & 63 & 15 \\
Euglena sp. & $14-20$ & $39-61$ & $14-18$ \\
Prymnesium sp. & $22-38$ & $28-45$ & $25-33$ \\
Anabaena sp. & $4-7$ & 48 & $25-30$ \\
Chlamydomonas sp. & $14-22$ & $43-56$ & $2.9-17$ \\
Spirulina maxima & $6-7$ & $60-71$ & $13-16$ \\
Spirogyra & $11-21$ & $6-20$ & $33-64$ \\
Tetraselmis & $16-45$ & 52 & 15 \\
\hline
\end{tabular}

Proteins, typically, make up $50 \%$ or more of the total biomass of actively growing microalgae [147] with an amino acid profile which is similar to the amino acid composition of the reference protein from the Food and Agriculture Organisation of the United Nations (FAO) for human nutrition [147]. The protein content of seaweed can be variable and low, especially in brown macroalgae and the proportions of essential amino acids can be nutritionally unbalanced [23,131]. However, high protein content can reduce the $\mathrm{C}: \mathrm{N}$ ratio and lead to excessive ammonia production from the degradation of amino acids $[148,149]$. The high concentrations of protein found in many microalgae can result in low methane yield due to ammonia toxicity derived from the breakdown of amino acids $[89,126,128]$. However, Tian et al. [150] have shown by developing a specialised acclimatised microbiome that methanogenic communities can tolerate excessive ammonia levels for biogas via AD continuous processes. The C:N ratio is discussed further in Section 5.6.

Polysaccharides are the principal component of seaweeds being up to $76 \%$ of the total dry weight, and typically $\sim 50 \%$ [23]. Algal polysaccharide composition is often different from that of terrestrial plants with the most important polysaccharides of brown algae being Laminarin, Mannitol, Alginate and Fucoidan [151]. Algae can also typically contain a more diverse range of monomeric sugars than terrestrial plants [152]. Algal polysaccharides are further discussed in Section 5.3.

The organic sulphur content of algae can be significant relative to terrestrial plants. Table 4 shows the elemental analysis of various seaweed species considered as potential biofuels. The high sulphur concentration in seaweed can also lead to the production of $\mathrm{H}_{2} \mathrm{~S}$ that inhibits methane production and produces foul odours; a corrosive environment; and sulphur dioxide emissions on biogas combustion $[21,154]$. The concentration of $\mathrm{H}_{2} \mathrm{~S}$ in biogas can be reduced by the addition of metal ions such as iron or by gas scrubbers, but both increase the cost of biogas production $[21,154]$.

Table 4. Compositional data $(\% \mathrm{dw})$ for species of seaweed being considered as potential biofuels.

\begin{tabular}{lllllll}
\hline Algae & Ash & Carbon & Hydrogen & Oxygen & Nitrogen & Sulphur \\
\hline Fucus vesiculosus $^{1}$ & 22.82 & 32.88 & 4.77 & 35.63 & 2.53 & 2.44 \\
Chorda filum $^{1}$ & 11.61 & 39.14 & 4.69 & 37.23 & 1.42 & 1.62 \\
Laminaria digitata $^{1}$ & 25.75 & 31.59 & 4.85 & 34.16 & 0.9 & 2.44 \\
Fucus serratus $^{1}$ & 23.36 & 33.5 & 4.78 & 34.44 & 2.39 & 1.31 \\
Laminaria hyperborea $^{1}$ & 17.97 & 34.97 & 5.31 & 35.09 & 1.12 & 2.06 \\
Macrocyctis pyrifera $^{1}$ & 38.35 & 27.3 & 4.08 & 34.8 & 2.03 & 1.89 \\
Laminaria saccharina $^{2}$ & 24.2 & 31.3 & 3.7 & 36.3 & 2.4 & 0.7 \\
Sargassum muticum $^{3}$ & 29.45 & 30.66 & 3.95 & 29.56 & 4.89 & 1.49 \\
\hline \multicolumn{7}{c}{${ }^{1}[45]^{2}[153]^{3}[22]}$. \\
\end{tabular}


The high ash content of both seaweeds (Table 4) and microalgae (Spirulina 7-10\% [155], diatoms 9-35\% [156]) results in algal biomass with a higher heating value (HHV) below that of the land energy crops (cf. 14-16 compared to 17-20 MJ $\cdot \mathrm{kg}^{-1}$ ) [45]. The ash content may also present problems for the disposal and use of residues after AD not only due to the quantity but also the presence of toxic heavy metals. Both seaweed and microalgae have an affinity for heavy metals [157,158]. Zeraatkar, et al. [157] has recently comprehensively reviewed the use of algae for heavy metal bioremediation.

\subsection{Cell Wall Architecture}

There are considerable differences between the cell wall architectures of algae; some have no cell wall, but the majority of species possess a cell wall with a structure very different to that of higher plants [159]. The greatest variation in cell wall composition is located in algae, as if "nature decided to conduct a vast experiment with algae to select from the numerous polysaccharides the one that suits a cell wall best" [160]. The cell walls of algae are usually fibrous composites of polysaccharide microfibrils embedded in a polysaccharides and proteoglycans matrix [161].

In the case of microalgae, strains of Chlorella, for example, the cell wall is a trilaminar outer layer (TLS) containing algaenan that is a very resistant and nonhydrolyzable aliphatic biopolymer, whilst other strains have a cell wall with no TLS outer layer but a greater percentage of the polysaccharide cellulose and other sugars notably glucosamine in their rigid walls [162]. The microalga D. salina does not have a true cell wall but has a cell membrane consisting of a lipid bilayer that can be readily damaged by hydrodynamic forces [163-165]. On the other hand, coccoliths surround their cells with an outer coating of calcium carbonate platelets [166,167]. Ganesh Saratale et al. [168] has suggested that in the AD of microalgae, wall characteristics (cell wall typically accounts for $11-37 \% \mathrm{dw}$ ) can be the most important parameter governing the efficiency of biogas production $[169,170]$. This is because considerable energy may be required for cell disruption [171,172], which may negatively impact on the EROI.

Not only do structural differences exist between the red, green, and brown seaweed, the polysaccharide make-up of the cell wall is also substantially different $[23,173,174]$. The primary skeletal cell wall component in brown algae is cellulose, while mannan, xylan and cellulose are key elements in green and red macroalgae $[23,173,175]$. The cell wall of brown seaweeds is typically an intricate structure of cellulose microfibrils embedded in a complex mix of alginate, sulphated fucans, hemicellulose, phenolics and proteinaceous compounds $[23,173,174,176]$. These complex interlinked network of microfibrils can be challenging to degrade enzymatically using cellulase and alginate lyase [177]. Both micro and macroalgal biomass may require pre-treatment before $\mathrm{AD}$ in order to break the cell wall structure to allow the microorganisms access to the organic components of the algae. Maneein et al. [42] have recently reviewed the pre-treatment of seaweed for fermentation and AD.

\subsection{Polysaccharide}

A study from Mussgnug et al. [124] examining the methane potential from six different (microalgae) species showed that a decrease of cell degradation correlates positively with the amount of biogas produced. Easily degradable species investigated did not have a cell wall (D. salina) or a protein-based cell wall containing no hemicellulose or cellulose (C. reinhardtii), A. platensis, E. gracilis). In contrast, C. kessleri and S. obliquus have carbohydrate-based cell walls containing hemicellulose which limits the AD process. The study suggests that various pre-treatment steps are required to enhance the hydrolysis and the anaerobic digestion.

The hydrolysis of seaweed-derived polysaccharides, frequently alginates, is often a rate-limiting step in seaweed AD $[29,178]$. Seaweed is known for complex polysaccharides of high molecular weight exhibiting high heterogeneity with some of the hydroxyl groups of the sugar residues substituted by half ester sulphate groups. These sulphated polysaccharides (SP) of seaweed are also chemically very different from those of vascular plants with sulphated galactans of periodical unit/linkage sequence (carrageenans, agars) typical for red algae, fucoidans, and alginates for brown algae; ulvans 
(sulphated glucuronoxylorhamnans) and other sulphated glycans for green algae [179,180]. These SPs constituents serve as storage and supporting structural tissue such as the cell wall. Their abundance differs with respect to species, period and season of seaweed harvest [181]. Typical polysaccharide content $(\% \mathrm{DW})$ is around $50 \%$ but can reach as high as $78 \%$ in certain species [23]. Dietary fibre content, which usually refers to indigestible carbohydrate content, is around $40 \%$ (\%DW) in the brown seaweed Sargassum muticum. Increasing surface area for microbial attack by reducing the size of the biomass should be done to increase biomethane yield but chemical attack/pre-treatment, for example, thermochemical hydrolysis of the biomass ( $3 \%$ sulfuric acid, $121{ }^{\circ} \mathrm{C}, 45 \mathrm{~min}$ ) is often required [42,181]. Future work could target the effect of different commercially available enzymes on seaweed pre-treatment or the development of a more specific enzymatic cocktail that could efficiently breakdown the seaweed polysaccharides achieving maximum substrate hydrolysis yields. Standard inocula for $\mathrm{AD}$ are usually from animal manure slurry and municipal sewage sludge, nevertheless inocula containing greater proportions of bacteria able to ferment marine phycocolloids have been demonstrated to improve methane production [29]. The addition of bacteria from sheep rumen that had a diet mainly of seaweed increased methane yield $\left(0.2531 \mathrm{CH}_{4} \mathrm{~g}^{-1} \mathrm{VS}\right)$ and volatile solid utilisation (67\%) from AD of Laminaria hyperborean [29].

\subsection{Phenolics}

Phenols are a varied group of compounds that have a hydroxyl group bonded to a benzenoid ring and are broadly distributed in algae and vascular plants with over $>8,000$ phenolic compounds being separated from terrestrial and marine organisms $[182,183]$. Algae and brown seaweeds in particular can contains considerable amounts of phenolics (up to $14 \%$ dry weight (dw)) [184]. The phenolics in algae can be very different from those of terrestrial plant with phlorotannins (based on phloroglucinol) being the predominant polyphenol in many seaweeds [184-187].

Phenolic compounds are thought to damage bacterial cells by altering the permeability of the cell membrane, resulting in leakage of intracellular components and inactivation of critical enzymes [135] For example, ethanol extracts of Ascophyllum nodosum associated with high phenolic content inhibited $\alpha$-glucosidase activity [188]. Methane yields can, therefore, be affected as this enzyme is involved in the hydrolysis stages of anaerobic digestion (Figure 1) [189]. Phenolic extracts from S. muticum have displayed antimicrobial activity against various aerobic bacteria [190]. High seasonal phenolic levels in Ascophyllum nodosum have been linked to decreased methane yields [191], and when polyphenols were 'fixed' in Ascophyllum nodosum by formaldehyde biogas production was improved [178,192]. Milledge et al. [192] found that although phenolic compounds did not appear to inhibit the breakdown of the simple and readily digested compounds, phenols could inhibit the breakdown of more complex molecules in the preliminary hydrolysis stage of AD. Similarly, polyphenols showed a negative impact on the degradation of seaweed using microbes from the rumen of sheep ewes [145]. An analysis of seasonal variation in Ascophyllum nodosum also indicated that variations in polyphenol content could affect methane yields (Figure 2) [191]. The biodegradability index (BI) represents the methane yields measured relative to the theoretical methane yields from the ultimate analysis, indicating the efficiency of the AD process. It was postulated that the increase in polyphenol content between June and September influenced the lower methane yields measured regardless of high C:N ratio between these months [191]. In addition to inhibitory effects of polyphenols, high ash content, including salts, relative to volatile solids content, can have an adverse compounding effect on methane yields [191]. 


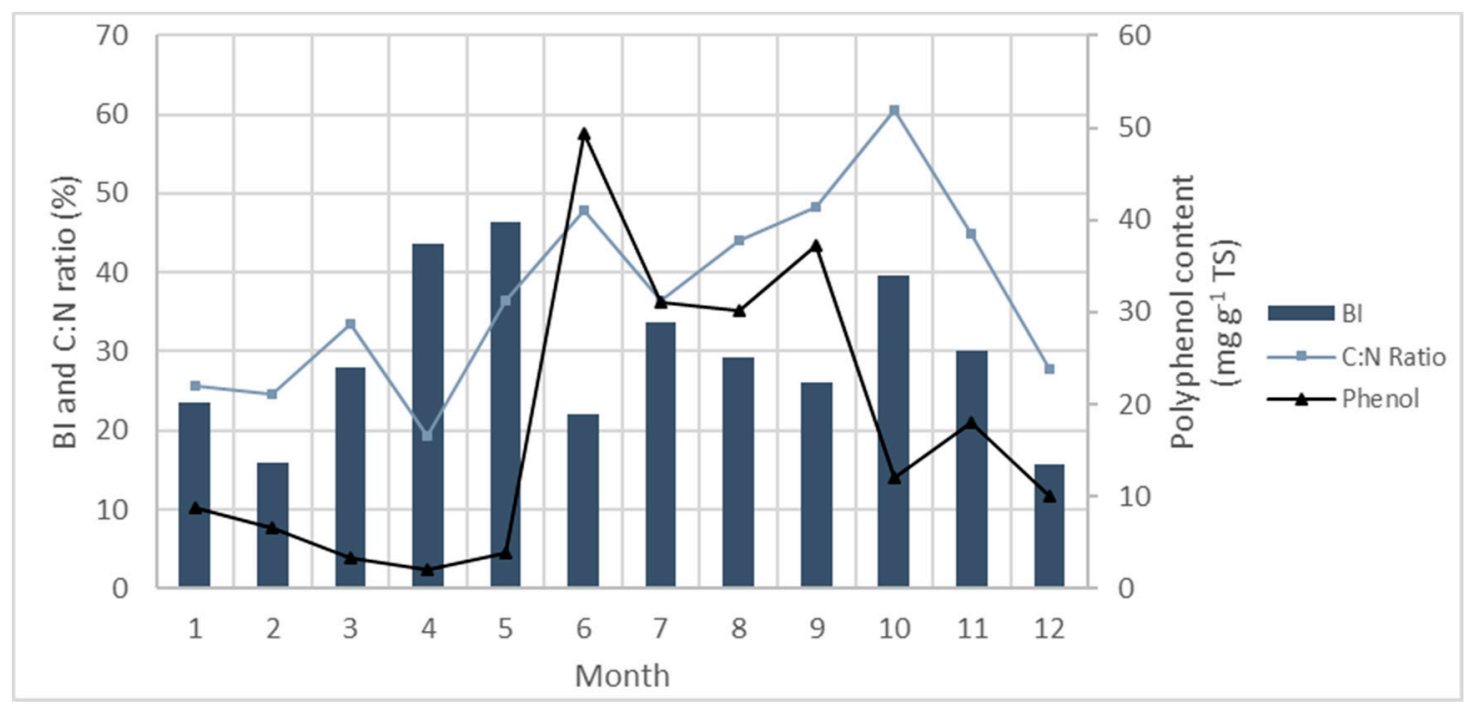

Figure 2. Annual variation in biodegradability index (BI) (BMP divided by theoretical methane yields), expressed in \%, of A. nodosum with variations in polyphenol content and C:N ratio. Polyphenol content is expressed in $\mathrm{mg} \mathrm{g}^{-1}$ total solids (TS). C:N ratio is expressed as the percentage of the sum of the ultimate analysis (C:N ratio divided by sum of \% ultimate analysis). Figure derived from data by Tabassum, et al. [191].

\subsection{Salt}

The growth of algae in a marine, brackish or hypersaline environments can result in the salt (sodium chloride) content of algae being higher than terrestrial plants; the content salt of unwashed Sargassum muticum is $15 \% \mathrm{dw}$ [120]. Washing with freshwater removes salt in the seaweed but increases production costs, and cultivated seaweed is, therefore, usually washed in commercial processes with filtered salt water.

Low salt concentrations can stimulate microbial growth. However, high salt concentrations $\left(\geq 10 \mathrm{~g} \cdot \mathrm{L}^{-1}\right)$ can inhibit AD due to a build-up of osmotic pressure and dehydration of methanogenic microorganisms $[193,194]$. The high salt content has been suggested as the "main obstacle associated with methane production" from marine algae AD [195].

The sodium cation principally governs salt toxicity but potassium and other light metal ions, at elevated levels, have also been found to be toxic to methanogens [149,196]. An optimal concentration of sodium for mesophilic methanogens in wastewater treatment of $230 \mathrm{mg} \mathrm{Na} \mathrm{L}^{-1}$ has been recommended [197]. At the level of sodium in seawater (14 $\mathrm{g} \mathrm{Na} \mathrm{L}^{-1}$ [197,198]), mesophilic methanogenic activity is reduced by $50 \%$ [199].

Algal biomass grown in saline environments is often washed in fresh water to reduce the salt [140]. The washing of Ulva, in fresh water, does not alter methane yield [99,200], even with a $2.5 \%$ reduction VS concentration and a $23 \%$ reduction in TS content of the green alga, as a result of the removal of sand and gravel [99]. Conversely, washing Laminaria digitata, although reducing the content of soluble carbohydrate, increased methane yield, perhaps due to decreased salt content [201]. Milledge et al. [202] found that the methane yield from AD was not statistically significantly different after washing in freshwater but washing delayed biomethane production.

Anaerobic digesters exposed to gradually increasing salt concentration can be acclimatised to higher salt levels [194,203]. The acclimation of methanogens to increased sodium concentrations over extended periods can allow the anaerobic breakdown of wet biomass with excessive salt concentration, with the sodium concentration that reduces methanogenic activity in half increasing to $37.4 \mathrm{~g} \mathrm{Na} \mathrm{L}^{-1}$ after acclimatisation [197]. A marine microbial inoculum, which can be obtained from marine sediment, seaweed microflora or seawater, could also be an excellent alternative to more conventional inocula [204]. Jard et al. [205] compared biomethane production of Saccharina latissimi in both batch and 
semi-continuous reactors with a $210 \mathrm{~mL} \mathrm{CH}_{4} \mathrm{~g}^{-1}$ VS yield from the batch reactor and $270 \mathrm{~mL} \mathrm{CH}_{4} \mathrm{~g}^{-1}$ VS from the semi-continuous process. Nevertheless, after 182 days of operation in semi-continuous experiments, a decrease in yield occurred due to inhibition from the accumulation of potassium and sodium.

An alternative approach could be the addition of small molecule osmolytes such as trehalose and betaine to the digester which are taken up the microorganisms to control osmotic pressure; the addition of such compound has been found to increase methogenic activity under osmotic stress [206,207]. Nonetheless, the cost of potential osmolytes could be a hurdle to their application in highly saline wastewater treatment, and the use of osmolytes to marine algae to improve methane yield in high salinity does not appear to have been greatly studied [206,207]. Although some proteins and amino acids can enhance methane production in saline environments [206,207], elevated levels of both salt and ammonia (from amino acid breakdown) can act synergistically to reduce methane yields with salt concentration of $10 \mathrm{~g} \cdot \mathrm{L}^{-1}$ together with ammonium concentration $200 \mathrm{mg} \cdot \mathrm{L}^{-1}$ reducing methane production from domestic sewage by $\sim 50 \%$ [208]. Dunaliella a halophytic alga with a high salt and protein content $(57 \%)$ can have a low methane yield, as little as $63 \mathrm{mg} \cdot \mathrm{L}^{-1} \mathrm{VS}$ despite the lack of a recalcitrant cell wall $[123,170]$.

It may be possible to produce biogas from algae without the need for fresh water, but the high salt concentration could also be mitigated by combining algal biomass with other forms of biomass to 'dilute' the salt [21] and production costs could be reduced if seawater is used as a liquid substrate with unwashed biomass.

\subsection{C:N and Co-digestion}

The carbon-to-nitrogen $\mathrm{C}: \mathrm{N}$ ratio is the proportion of the mass of carbon relative to the mass of nitrogen in biomass and has a considerable effect on it biodegradability by both aerobic and anaerobic processes $[209,210]$. The C:N ratio optimal for anaerobic conversion of biomass to methane is $\sim 30$ : to preclude lower methane yields due to ammonia inhibition resulting from the breakdown of organic nitrogen compounds [118,209-212]. Many algae both macro and micro have a low C:N ratio. Microalgae typically have a $\mathrm{C}: \mathrm{N}$ ratio $\sim 6$ and macroalgae have a more variable ratio but typically $\sim 15[159,170,213]$. The C:N ratio for Sargassum muticum is 6-20 depending on location and season [22,118-120,214], and the C:N for floating mixed Sargassum mats (S. natans and S. fluitans) varied widely from $23-47[215,216]$, although a low C:N ratio of 7 has been reported for S. natans [217]. The low C:N content (10-25) Ulva lactuca was one limiting factor in biogas production from its biomass [99]. Tedesco and Daniels [109] showed that by increasing C:N ratio from 8.5 to 24.7 in Fucus serratus biomass, by solvent extraction, the methane yield per gram of VS increased by up to $70 \%$. However, no correlation was found between methane yield and C:N ratio for four species of microalgae (Chlorella, Dunaliella, Nostoc and Scenedesmus) having low C:N ratios (4.8-12.6) [170], and may be due to the C:N being substantially below the optimum $\sim 30$; ratios $<20$ can result in reduced methane yield due to ammonia inhibition from amino acid breakdown [123].

Carbon-rich biomass can be added to the digester to increase the low C:N ratio of algae and reduce the inhibitory effects of ammonia [218]. Many reports suggest a co-digestion process with an improved C:N ratio can deliver economic viability in addition to other benefits such as better biogas yield; improved buffering capacity; dilution of inhibitory compounds; and improved nutrient balance [168,219]. The co-digestion of Sargassum spp. with waste cooking oil or glycerol, containing little nitrogen, improved methane yield by $19-56 \%$ relative to the different materials digested individually [220]. S. muticum co-digested with unrefined glycerol from biodiesel production increased biogas yield by 27\% [120]. In Solrod (Denmark), where beach-cast seaweed has been co-digested with organic residues such as cattle manure; the best process performance from the environmental perspective was achieved with a 20:80 mixture of beach-cast seaweed and manure Economic feasibility analysis suggested that if transportation costs of seaweed biomass are taken into consideration a positive Net Present Value 
(NPV) is not achievable. However, the process technology can form a part of the integrated system for efficient energy production and optimisation of resources [221].

\section{Conclusions}

Algal biomass represents a potential green bioenergy source for the production of biomethane when processed using AD methods. However algal biomethane production processes are currently unprofitable and unsustainable unless considered as an adjunct to processes that aim for a circular economy such as wastewater treatment, reduction of eutrophication, or zero-waste objectives in algal biorefineries. Limitations include harvesting costs from water bodies, pre-treatment and seasonal variation in biomass composition and yield, as well as operational costs aimed at improving biomethane conversion yield. Wastewater treatment ponds are currently the most economic approach to the production of microalgal biofuel.

Author Contributions: Conceptualisation, J.J.M. and B.V.N.; writing—original draft preparation, J.J.M., B.V.N. and S.M.; writing—review and editing, J.J.M., B.V.N. and P.J.H.; supervision, J.J.M., B.V.N. and P.J.H.

Funding: The author would like to acknowledge the financial support of the University of Greenwich and the Doctoral Training Alliance.

Conflicts of Interest: The authors declare no conflict of interest.

\section{References}

1. Chen, H.; Qiu, T.; Rong, J.; He, C.; Wang, Q. Microalgal biofuel revisited: An informatics-based analysis of developments to date and future prospects. Appl. Energy 2015, 155, 585-598. [CrossRef]

2. Kerrison, P.D.; Stanley, M.S.; Edwards, M.D.; Black, K.D.; Hughes, A.D. The cultivation of European kelp for bioenergy: Site and species selection. Biomass Bioenergy 2015, 80, 229-242. [CrossRef]

3. Milledge, J.J.; Harvey, P.J. Potential process 'hurdles' in the use of macroalgae as feedstock for biofuel production in the British Isles. J. Chem. Technol. Biotechnol. 2016, 91, 2221-2234. [CrossRef] [PubMed]

4. Milledge, J.J;; Heaven, S. Methods of energy extraction from microalgal biomass: A review. Rev. Environ. Sci. Biotechnol. 2014, 13, 301-320. [CrossRef]

5. Milledge, J.J.; Smith, B.; Dyer, P.; Harvey, P. Macroalgae-Derived Biofuel: A Review of Methods of Energy Extraction from Seaweed Biomass. Energies 2014, 7, 7194-7222. [CrossRef]

6. Sills, D.L.; Paramita, V.; Franke, M.J.; Johnson, M.C.; Akabas, T.M.; Greene, C.H.; Tester, J.W. Quantitative Uncertainty Analysis of Life Cycle Assessment for Algal Biofuel Production. Environ. Sci. Technol. 2012, 47, 687-694. [CrossRef] [PubMed]

7. Fasaei, F.; Bitter, J.H.; Slegers, P.M.; van Boxtel, A.J.B. Techno-economic evaluation of microalgae harvesting and dewatering systems. Algal Res. 2018, 31, 347-362. [CrossRef]

8. Collet, P.; Helias, A.; Lardon, L.; Steyer, J.P.; Bernard, O. Recommendations for Life Cycle Assessment of algal fuels. Appl. Energy 2015, 154, 1089-1102. [CrossRef]

9. Milledge, J.J.; Heaven, S. A review of the harvesting of micro-algae for biofuel production. Rev. Environ. Sci. Biotechnol. 2013, 12, 165-178. [CrossRef]

10. Wang, S.-K.; Stiles, A.R.; Guo, C.; Liu, C.-Z. Harvesting microalgae by magnetic separation: A review. Algal Res. 2015, 9, 178-185. [CrossRef]

11. Molina Grima, E.; Belarbi, E.-H.; Acien-Fernandez, F.G.; Robles-Medina, A.; Yusuf, C. Recovery of microalgal biomass and metabolites: Process options and economics. Biotechnol. Adv. 2003, 20, 491-515. [CrossRef]

12. Zamalloa, C.; Vulsteke, E.; Albrecht, J.; Verstraete, W. The techno-economic potential of renewable energy through the anaerobic digestion of microalgae. Bioresour. Technol. 2011, 102, 1149-1158. [CrossRef]

13. Uduman, N.; Qi, Y.; Danquah, M.K.; Forde, G.M.; Hoadley, A. Dewatering of microalgal cultures: A major bottleneck to algae-based fuels. J. Renew. Sustain. Energy 2010, 2, 012701. [CrossRef]

14. Reynolds, C.S. The Ecology of Freshwater Phytoplankton; Cambridge University Press: Cambridge, UK, 1984.

15. Edzwald, J.K. Algae, bubbles, coagulants, and dissolved air flotation. Water Sci. Technol. 1993, 27, 67-81. [CrossRef]

16. Moraine, R.; Shelef, G.; Meydan, A.; Levi, A. Algal single cell protein from wastewater-treatment and renovation process. Biotechnol. Bioeng. 1979, 21, 1191-1207. [CrossRef] 
17. Packer, M. Algal capture of carbon dioxide; biomass generation as a tool for greenhouse gas mitigation with reference to New Zealand energy strategy and policy. Energy Policy 2009, 37, 3428-3437. [CrossRef]

18. Bruton, T.; Lyons, H.; Lerat, Y.; Stanley, M.; Rasmussen, M.B. A Review of the Potential of Marine Algae as a Source of Biofuel in Ireland; Sustainable Energy Ireland: Dublin, Ireland, 2009.

19. Milledge, J.J.; Staple, A.; Harvey, P. Pyrolysis of Invasive Seaweed Species. In Proceedings of the British Phycological Society Annual Meeting, Galway, Ireland, 25-27 June 2014.

20. Horn, S.V. Bioenergy from Brown Seaweeds; Norwegian University of Science and Technology (NTNU): Trondheim, Norway, 2000.

21. Murphy, F.; Devlin, G.; Deverell, R.; McDonnell, K. Biofuel Production in Ireland-An Approach to 2020 Targets with a Focus on Algal Biomass. Energies 2013, 6, 6391-6412. [CrossRef]

22. Milledge, J.J.; Staple, A.; Harvey, P. Slow Pyrolysis as a Method for the Destruction of Japanese Wireweed, Sargassum muticum. Environ. Nat. Resour. Res. 2015, 5, 28-36. [CrossRef]

23. Seaweed Sustainability: Food and Non-Food Applications, 1st ed.; Tiwari, B., Troy, D., Eds.; Academic Press: Amsterdam, The Nertherlands, 2015.

24. Peu, P.; Sassi, J.F.; Girault, R.; Picard, S.; Saint-Cast, P.; Béline, F.; Dabert, P. Sulphur fate and anaerobic biodegradation potential during co-digestion of seaweed biomass (Ulva sp.) with pig slurry. Bioresour. Technol. 2011, 102, 10794-10802. [CrossRef]

25. Vanegas, C.H.; Bartlett, J. Green energy from marine algae: Biogas production and composition from the anaerobic digestion of Irish seaweed species. Environ. Technol. 2013, 34, 2277-2283. [CrossRef]

26. Barbot, Y.; Al-Ghaili, H.; Benz, R. A Review on the Valorization of Macroalgal Wastes for Biomethane Production. Mar. Drugs 2016, 14, 120. [CrossRef] [PubMed]

27. Aresta, M.; Dibenedetto, A.; Barberio, G. Utilization of macro-algae for enhanced $\mathrm{CO}_{2}$ fixation and biofuels production: Development of a computing software for an LCA study. Fuel Process. Technol. 2005, 86, 1679-1693. [CrossRef]

28. Allen, E.; Wall, D.M.; Herrmann, C.; Xia, A.; Murphy, J.D. What is the gross energy yield of third generation gaseous biofuel sourced from seaweed? Energy 2015, 81, 352-360. [CrossRef]

29. Sutherland, A.; Varela, J. Comparison of various microbial inocula for the efficient anaerobic digestion of Laminaria hyperborea. BMC Biotechnol. 2014, 14, 7. [CrossRef] [PubMed]

30. Huesemann, M.; Roesjadi, G.; Benemann, J.; Metting, F.B. Biofuels from Microalgae and Seaweeds. In Biomass to Biofuels; Blackwell Publishing Ltd.: Oxford, UK, 2010; pp. 165-184.

31. Lewis, J.; Salam, F.; Slack, N.; Winton, M.; Hobson, L. Product Options for the Processing of Marine Macro-Algae-Summary Report; The Crown Estates: London, UK, 2011.

32. Clarens, A.F.; Nassau, H.; Resurreccion, E.P.; White, M.A.; Colosi, L.M. Environmental Impacts of Algae-Derived Biodiesel and Bioelectricity for Transportation. Environ. Sci. Technol. 2011, 45, 7554-7560. [CrossRef] [PubMed]

33. Cleveland, C.J.; O'Connor, P.A. Energy Return on Investment (EROI) of Oil Shale. Sustainability 2011, 3, 2307-2322. [CrossRef]

34. Beal, C.M. Algal Biofuels: Energy and Water. In Proceedings of the WEG Symposium, Austin, TX, USA, 21-22 January 2011.

35. Mulder, K.; Hagens, N.J. Energy return on investment: Toward a consistent framework. Ambio 2008, 37, 74-79. [CrossRef]

36. Hall, C.A.S.; Klitgaard, K.A. Energy and the Wealth of Nations: Understanding the Biophysical Economy; Springer: New York, NY, USA, 2012.

37. Twidell, J.; Weir, T. Renewable Energy Sources, 2nd ed.; Taylor \& Francis: London, UK, 2006.

38. Alvarado-Morales, M.; Boldrin, A.; Karakashev, D.B.; Holdt, S.L.; Angelidaki, I.; Astrup, T. Life cycle assessment of biofuel production from brown seaweed in Nordic conditions. Bioresour. Technol. 2013, 129, 92-99. [CrossRef]

39. Aitken, D.; Bulboa, C.; Godoy-Faundez, A.; Turrion-Gomez, J.L.; Antizar-Ladislao, B. Life cycle assessment of macroalgae cultivation and processing for biofuel production. J. Clean. Prod. 2014, 75, 45-56. [CrossRef]

40. Aitken, D. An Assessment of the Sustainability of Bioenergy Production from Algal Feedstock; The University of Edinburgh: Edinburgh, UK, 2014. 
41. Pechsiri, J.S.; Thomas, J.-B.E.; Risén, E.; Ribeiro, M.S.; Malmström, M.E.; Nylund, G.M.; Jansson, A.; Welander, U.; Pavia, H.; Gröndahl, F. Energy performance and greenhouse gas emissions of kelp cultivation for biogas and fertilizer recovery in Sweden. Sci. Total Environ. 2016, 573, 347-355. [CrossRef] [PubMed]

42. Maneein, S.; Milledge, J.J.; Nielsen, B.V.; Harvey, P.J. A Review of Seaweed Pre-Treatment Methods for Enhanced Biofuel Production by Anaerobic Digestion or Fermentation. Fermentation 2018, 4, 100. [CrossRef]

43. Chen, H.; Zhou, D.; Luo, G.; Zhang, S.; Chen, J. Macroalgae for biofuels production: Progress and perspectives. Renew. Sustain. Energy Rev. 2015, 47, 427-437. [CrossRef]

44. Lundquist, T.J.; Woertz, I.C.; Quinn, N.W.T.; Benemann, J.R. A Realistic Technology and Engineering Assessment of Algae Biofuel Production; Energy Biosciences Institute: Berkeley, CA, USA, 2010.

45. Ross, A.B.; Jones, J.M.; Kubacki, M.L.; Bridgeman, T. Classification of macroalgae as fuel and its thermochemical behaviour. Bioresour. Technol. 2008, 99, 6494-6504. [CrossRef] [PubMed]

46. Milledge, J.J.; Harvey, P.J. Anaerobic digestion and gasification of seaweed. In Grand Challenges in Marine Biotechnology; Rampelotto, P.H., Trincone, A., Eds.; Spinger: Cham, Switzerland, 2018.

47. Chisti, Y. Biodiesel from microalgae. Biotechnol. Adv. 2007, 25, 294-306. [CrossRef]

48. Islam, M.A.; Heimann, K.; Brown, R.J. Microalgae biodiesel: Current status and future needs for engine performance and emissions. Renew. Sustain. Energy Rev. 2017, 79, 1160-1170. [CrossRef]

49. Lardon, L.; Helias, A.; Sialve, B.; Stayer, J.P.; Bernard, O. Life-Cycle Assessment of Biodiesel Production from Microalgae. Environ. Sci. Technol. 2009, 43, 6475-6481. [CrossRef]

50. Liu, X.; Clarens, A.F.; Colosi, L.M. Meta-model of Algae Bio Energy Life Cycles (MABEL). In Proceedings of the LCA XI Conference, Chicago, IL, USA, 6 October 2011.

51. Garofalo, R. Algae and Aquatic Biomass for a Sustainable Production of 2nd Generation Biofuels. Deliverables 3.3 and 3.5 Lifecycle Assessment and Environmental Assessment; Aqua Fuels: Brussels, Belgium, 2011.

52. ter Veld, F. Beyond the Fossil Fuel Era: On the Feasibility of Sustainable Electricity Generation Using Biogas from Microalgae. Energy Fuels 2012, 26, 3882-3890. [CrossRef]

53. Milledge, J.J.; Heaven, S. Energy Balance of Biogas Production from Microalgae: Effect of Harvesting Method, Multiple Raceways, Scale of Plant and Combined Heat and Power Generation. J. Mar. Sci. Eng. 2017, 5, 9. [CrossRef]

54. Milledge, J.J.; Heaven, S. Energy Balance of Biogas Production from Microalgae: Development of an Energy and Mass Balance Model. Curr. Biotechnol. 2015, 4, 554-567. [CrossRef]

55. Gouveia, L. Microalgae as a Feedstock for Biofuels; Springer: Heidelberg, Germany, 2011.

56. Park, J.B.K.; Craggs, R.J.; Shilton, A.N. Wastewater treatment high rate algal ponds for biofuel production. Bioresour. Technol. 2011, 102, 35-42. [CrossRef]

57. Oswald, W.J. Large-scale algal culture systems (engineering aspects). In Micro-algal Biotechnology; Borowitzka, M.A., Borowitzka, L.J., Eds.; Cambridge University Press: Cambridge, UK, 1988.

58. Bowyer, J.; Howe, J.; Levins, R.; Groot, H.; Fernholz, K.; Pepke, E.; Henderson, C. Third Generation Biofuels Implications for Wood-Derived Fuels. Available online: http:/ / www.dovetailinc.org/report_pdfs/2018/ dovetail3gbiofuel0218.pdf (accessed on 28 February 2019).

59. Green, F.B.; Lundquist, T.J.; Oswald, W.J. Energetics of advanced integrated waste-water pond systems. Water Sci. Technol. 1995, 31, 9-20. [CrossRef]

60. Goldman, J.C. Outdoor algal mass cultures-I. Applications. Water Res. 1979, 13, 1-19. [CrossRef]

61. Buhr, H.O.; Miller, S.B. A dynamic model of the high rate algal bacterial waste water treatment pond. Water Res. 1983, 17, 29-38. [CrossRef]

62. Jimoh, T.A.; Cowan, A.K. Extracellular polymeric substance production in high rate algal oxidation ponds. Water Sci. Technol. 2017, 76, 2647-2654. [CrossRef]

63. Williams, P.J.1.B.; Laurens, L.M.L. Microalgae as biodiesel \& biomass feedstocks: Review \& analysis of the biochemistry, energetics \& economics. Energy Environ. Sci. 2010, 3, 554-590.

64. Singh, A.K.; Sharma, N.; Farooqi, H.; Abdin, M.Z.; Mock, T.; Kumar, S. Phycoremediation of municipal wastewater by microalgae to produce biofuel. Int. J. Phytoremediation 2017, 19, 805-812. [CrossRef]

65. Benemann, J.; Koopman, B.; Weissman, J.; Eisenberg, D.; Goebel, R. Development of microalgae harvesting and high-rate pond technologies in California. In Algae Biomass; Shelef, G., Soeder, C.J., Eds.; Elsevier: Amsterdam, The Nertherlands, 1980.

66. James, S.C.; Boriah, V. Modeling Algae Growth in an Open-Channel Raceway. J. Comput. Biol. 2010, 17, 895-906. [CrossRef] 
67. Sheehan, J.; Dunahay, T.; Benemann, J.; Roessler, P. A Look Back at the US Department of Energy's Aquatic Species Program-Biodiesel from Algae; NREL/TP-580-24190; National Renewable Energy Laboratory NREL: Golden, CO, USA, 1998; p. 7.

68. Benemann, J.; Oswald, W.J. Systems and Economic Analysis of Microalgae Ponds for Conversion of $\mathrm{CO}_{2}$ to Biomass; Pittsburgh Energy Technology Centre: Pittsburgh, PA, USA, 1996.

69. Olguín, E.J. Phycoremediation: Key issues for cost-effective nutrient removal processes. Biotechnol. Adv. 2003, 22, 81-91. [CrossRef]

70. Borowitzka, M.A. Commercial production of microalgae: Ponds, tanks, tubes and fermenters. J. Biotechnol. 1999, 70, 313-321. [CrossRef]

71. Brennan, L.; Owende, P. Biofuels from microalgae-A review of technologies for production, processing, and extractions of biofuels and co-products. Renew. Sustain. Energy Rev. 2010, 14, 557-577. [CrossRef]

72. Jimenez, C.; Cossio, B.R.; Niell, F.X. Relationship between physicochemical variables and productivity in open ponds for the production of Spirulina: A predictive model of algal yield. Aquaculture 2003, 221, 331-345. [CrossRef]

73. Johnson, D.A.; Weissman, J.C.; Goebel, R.P. An Outdoor Test Facility for Large Scale Production of Microalgae; SERI/TP-231-3325; SERI: Golden, CO, USA, 1988.

74. Aquafuels. Algae and Aquatic Biomass for a Sustainable Production of 2 nd Generation Biofuels; Aquafuels: Brussels, Belgium, 2011.

75. Weissman, J.C.; Tillett, D.M.; Goebel, R.P. Design and Operation of an Outdoor Microalgae Test Facility; SERI/STR-232-3569; SERI: Golden, CO, USA, 1989.

76. Terry, K.L.; Raymond, L.P. System-design for the autotrophic production of microalgae. Enzym. Microb. Technol. 1985, 7, 474-487. [CrossRef]

77. Borowitzka, M.A. Culturing of Microalgae in Outdoor Ponds. In Algal Culturing Techniques; Andersen, R.A., Ed.; Elsevier: London, UK, 2005.

78. Chiaramonti, D.; Prussi, M.; Casini, D.; Tredici, M.R.; Rodolfi, L.; Bassi, N.; Zittelli, G.C.; Bondioli, P. Review of energy balance in raceway ponds for microalgae cultivation: Re-thinking a traditional system is possible. Appl. Energy 2013, 102, 101-111. [CrossRef]

79. Craggs, R.; Park, J.; Heubeck, S.; Sutherland, D. High rate algal pond systems for low-energy wastewater treatment, nutrient recovery and energy production. N. Z. J. Bot. 2014, 52, 60-73. [CrossRef]

80. Ahrens, T.; Sander, H. Microalgae in Waste Water Treatment; Green Gold from Sludge? Bioforum Eur. 2010, $14,16-18$.

81. Kazamia, E.; Aldridge, D.C.; Smith, A.G. Synthetic ecology-A way forward for sustainable algal biofuel production? J. Biotechnol. 2012, 162, 163-169. [CrossRef]

82. Smith, V.H.; Sturm, B.S.M.; de Noyelles, F.J.; Billings, S.A. The ecology of algal biodiesel production. Trends Ecol. Evol. 2010, 25, 301-309. [CrossRef]

83. Godwin, C.M.; Lashaway, A.R.; Hietala, D.C.; Savage, P.E.; Cardinale, B.J. Biodiversity improves the ecological design of sustainable biofuel systems. Glob. Chang. Biol. Bioenergy 2018, 10, 752-765. [CrossRef]

84. Committee on the Sustainable Development of Algal Biofuels. Sustainable Development of Algal Biofuels in the United States; The National Academies Press: Washington, DC, USA, 2012.

85. Kazamia, E.; Riseley, A.S.; Howe, C.J.; Smith, A.G. An Engineered Community Approach for Industrial Cultivation of Microalgae. Ind. Biotechnol. 2014, 10, 184-190. [CrossRef] [PubMed]

86. Mambo, P.; Westensee, D.; Zuma, B.; Cowan, A.K. The Belmont Valley integrated algae pond system in retrospect. Water $S A$ 2014, 40. [CrossRef]

87. Singh, A.; Olsen, S.I. A critical review of biochemical conversion, sustainability and life cycle assessment of algal biofuels. Appl. Energy 2011, 88, 3548-3555. [CrossRef]

88. Ward, A.J.; Lewis, D.M.; Green, B. Anaerobic digestion of algae biomass: A review. Algal Res.-Biomass Biofuels Bioprod. 2014, 5, 204-214. [CrossRef]

89. Golueke, C.G.; Oswald, W.J. Biological conversion of light energy to the chemical energy of methane. Appl. Microbiol. 1959, 7, 219-227. [PubMed]

90. Tran, K.C. Anaerobic Digestion of Microalgal Biomass: Effects of Solid Concentration and Pre-Treatment. Ph.D. Thesis, University of Southampton, Southampton, UK, 2017. 
91. Glaz, P.; Bartosiewicz, M.; Laurion, I.; Reichwaldt, E.S.; Maranger, R.; Ghadouani, A. Greenhouse gas emissions from waste stabilisation ponds in Western Australia and Quebec (Canada). Water Res. 2016, 101, 64-74. [CrossRef]

92. All-gas. All-gas Newsletter 11/2017. Available online: http://www.all-gas.eu/documents/1509955/ 1514023/Newsletter_2017.11_eng.pdf/629a9f4c-17e4-4cca-0b8f-b1b8bbe855ca (accessed on 17 January 2019).

93. Maga, D. Life cycle assessment of biomethane produced from microalgae grown in municipal waste water. Biomass Convers. Biorefinery 2017, 7, 1-10. [CrossRef]

94. Benzie, J.A.H.; Hynes, S. Bioenergy Production by Anaerobic Digestion: Using Agricultural Biomass and Organic Wastes. In Bioenergy Production by Anaerobic Digestion; Korres, N., O’Kiely, P., Benzie, J., West, J., Eds.; Routledge: London, UK, 2013.

95. Food and Agriculture Organisation of the United Nations. Statistical Collections. Available online: http: / / www.fao.org/fishery/statistics/collections/en (accessed on 17 December 2018).

96. Xia, A.; Cheng, J.; Murphy, J.D. Innovation in biological production and upgrading of methane and hydrogen for use as gaseous transport biofuel. Biotechnol. Adv. 2016, 34, 451-472. [CrossRef] [PubMed]

97. Herrmann, C.; FitzGerald, J.; O'Shea, R.; Xia, A.; O'Kiely, P.; Murphy, J.D. Ensiling of seaweed for a seaweed biofuel industry. Bioresour. Technol. 2015, 196, 301-313. [CrossRef]

98. Sode, S.; Bruhn, A.; Balsby, T.J.S.; Larsen, M.M.; Gotfredsen, A.; Rasmussen, M.B. Bioremediation of reject water from anaerobically digested waste water sludge with macroalgae (Ulva lactuca, Chlorophyta). Bioresour. Technol. 2013, 146, 426-435. [CrossRef] [PubMed]

99. Bruhn, A.; Dahl, J.; Nielsen, H.B.; Nikolaisen, L.; Rasmussen, M.B.; Markager, S.; Olesen, B.; Arias, C.; Jensen, P.D. Bioenergy potential of Ulva lactuca: Biomass yield, methane production and combustion. Bioresour. Technol. 2011, 102, 2595-2604. [CrossRef]

100. Nikolaisen, L.; Daugbjerg Jensen, P.; Svane Bech, K.; Dahl, J.; Busk, J.; Brødsgaard, T.; Schmidt, E.R. Energy Production from Marine Biomass (Ulva lactuca); Danish Technological Institute: Taastrup, Denmark, 2011.

101. Chynoweth, D.P.; Owens, J.M.; Legrand, R. Renewable methane from anaerobic digestion of biomass. Renew. Energy 2001, 22, 1-8. [CrossRef]

102. Jingura, R.M.; Kamusoko, R. Methods for determination of biomethane potential of feedstocks: A review. Biofuel Res. J. 2017, 4, 573-586. [CrossRef]

103. HELCOM. HELCOM Thematic Assessment of Eutrophication 2011-2016; Baltic Marine Environment Protection Commission-HELCOM Helsinki: Helsinki, Finland, 2018.

104. Fox, S.E.; Stieve, E.; Valiela, I.; Hauxwell, J.; McClelland, J. Macrophyte abundance in Waquoit Bay: Effects of land-derived nitrogen loads on seasonal and multi-year biomass patterns. Estuar. Coasts 2008, 31, 532-541. [CrossRef]

105. Duarte, C.M.; Wu, J.; Xiao, X.; Bruhn, A.; Krause-Jensen, D. Can seaweed farming play a role in climate change mitigation and adaptation? Front. Mar. Sci. 2017, 4. [CrossRef]

106. Pastare, L.; Romagnoli, F.; Lauka, D.; Dzene, I.; Kuznecova, T. Sustainable Use Of Macro-Algae For Biogas Production in Latvian Conditions: A Preliminary Study Through an Integrated MCA and LCA Approach. Environ. Clim. Technol. 2014, 13, 44. [CrossRef]

107. Balina, K.; Romagnoli, F.; Blumberga, D. Seaweed biorefinery concept for sustainable use of marine resources. Energy Procedia 2017, 128, 504-511. [CrossRef]

108. Mhatre, A.; Gore, S.; Mhatre, A.; Trivedi, N.; Sharma, M.; Pandit, R.; Anil, A.; Lali, A. Effect of multiple product extractions on bio-methane potential of marine macrophytic green alga Ulva lactuca. Renew. Energy 2019, 132, 742-751. [CrossRef]

109. Tedesco, S.; Daniels, S. Optimisation of biogas generation from brown seaweed residues: Compositional and geographical parameters affecting the viability of a biorefinery concept. Appl. Energy 2018, 228, 712-723. [CrossRef]

110. Rajendran, K.; Browne, J.D.; Murphy, J.D. What is the level of incentivisation required for biomethane upgrading technologies with carbon capture and reuse? Renew. Energy 2019, 133, 951-963. [CrossRef]

111. European Academies' Science Advisory Council. Negative Emission Technologies: What Role in Meeting Paris Agreement Targets? Leopoldina: Halle, Germany, 2018.

112. Mayfield, S.P. Consortium for Algal Biofuel Commercialization (CAB-COMM) Final Report; EE0003373; UC San Diego: La Jolla, CA, USA, 2015; 69p. 
113. Astals, S.; Musenze, R.S.; Bai, X.; Tannock, S.; Tait, S.; Pratt, S.; Jensen, P.D. Anaerobic co-digestion of pig manure and algae: Impact of intracellular algal products recovery on co-digestion performance. Bioresour. Technol. 2015, 181, 97-104. [CrossRef]

114. Banks, C.; Zhang, Y. Optimising Inputs and Outputs from Anaerobic Digestion Processes-Technical Report; Defra: Southampton, UK, 2010.

115. Golueke, C.G.; Oswald, W.J.; Gotaas, H.B. Anaerobic digestion of algae. Appl. Microbiol. 1957, 5, 47-55. [PubMed]

116. Nallathambi Gunaseelan, V. Anaerobic digestion of biomass for methane production: A review. Biomass Bioenergy 1997, 13, 83-114. [CrossRef]

117. Nguyen, H.; Heaven, S.; Banks, C. Energy potential from the anaerobic digestion of food waste in municipal solid waste stream of urban areas in Vietnam. Int. J. Energy Environ. Eng. 2014, 5, 365-374. [CrossRef]

118. Jard, G.; Marfaing, H.; Carrere, H.; Delgenes, J.P.; Steyer, J.P.; Dumas, C. French Brittany macroalgae screening: Composition and methane potential for potential alternative sources of energy and products. Bioresour. Technol. 2013, 144, 492-498. [CrossRef]

119. Soto, M.; Vazquez, M.A.; de Vega, A.; Vilarino, J.M.; Fernandez, G.; de Vicente, M.E. Methane potential and anaerobic treatment feasibility of Sargassum muticum. Bioresour Technol 2015, 189, 53-61. [CrossRef] [PubMed]

120. Milledge, J.J.; Harvey, P.J. Ensilage and anaerobic digestion of Sargassum muticum. J. Appl. Phycol. 2016, 28, 3021-3030. [CrossRef]

121. Roberts, K.P.; Heaven, S.; Banks, C.J. Comparative testing of energy yields from micro-algal biomass cultures processed via anaerobic digestion. Renew. Energy 2016, 87 Pt 1, 744-753. [CrossRef]

122. Passos, F.; Gutiérrez, R.; Brockmann, D.; Steyer, J.-P.; García, J.; Ferrer, I. Microalgae production in wastewater treatment systems, anaerobic digestion and modelling using ADM1. Algal Res. 2015, 10, 55-63. [CrossRef]

123. Fernandez-Rodriguez, M.J.; Rincon, B.; Fermoso, F.G.; Jimenez, A.M.; Borja, R. Assessment of two-phase olive mill solid waste and microalgae co-digestion to improve methane production and process kinetics. Bioresour. Technol. 2014, 157, 263-269. [CrossRef]

124. Mussgnug, J.H.; Klassen, V.; Schluter, A.; Kruse, O. Microalgae as substrates for fermentative biogas production in a combined biorefinery concept. J. Biotechnol. 2010, 150, 51-56. [CrossRef]

125. McKennedy, J.; Sherlock, O. Anaerobic digestion of marine macroalgae: A review. Renew. Sustain. Energy Rev. 2015, 52, 1781-1790. [CrossRef]

126. Samson, R.; LeDuy, A. Improved performance of anaerobic digestion of Spirulina maxima algal biomass by addition of carbon-rich wastes. Biotechnol. Lett. 1983, 5, 677-682. [CrossRef]

127. Gonzalez-Fernandez, C.; Sialve, B.; Bernet, N.; Steyer, J.P. Impact of microalgae characteristics on their conversion to biofuel. Part II: Focus on biomethane production. Biofuels Bioprod. Biorefining 2012, 6, 205-218. [CrossRef]

128. Park, S.; Li, Y.B. Evaluation of methane production and macronutrient degradation in the anaerobic co-digestion of algae biomass residue and lipid waste. Bioresour. Technol. 2012, 111, 42-48. [CrossRef]

129. Weiland, P. Biogas production: Current state and perspectives. Appl. Microbiol. Biotechnol. 2010, 85, 849-860. [CrossRef] [PubMed]

130. Heaven, S.; Milledge, J.; Zhang, Y. Comments on 'Anaerobic digestion of microalgae as a necessary step to make microalgal biodiesel sustainable'. Biotechnol. Adv. 2011, 29, 164-167. [CrossRef]

131. Øverland, M.; Mydland, L.T.; Skrede, A. Marine macroalgae as sources of protein and bioactive compounds in feed for monogastric animals. J. Sci. Food Agric. 2019, 99, 13-24. [CrossRef]

132. Becker, E.W. Microalgae. Biotechnology \& Microbiology; Cambridge University Press: Cambridge, UK, 1994.

133. Leal, M.C.; Munro, M.H.G.; Blunt, J.W.; Puga, J.; Jesus, B.; Calado, R.; Rosa, R.; Madeira, C. Biogeography and biodiscovery hotspots of macroalgal marine natural products. Nat. Prod. Rep. 2013, 30, 1380-1390. [CrossRef] [PubMed]

134. Tabassum, M.R.; Xia, A.; Murphy, J.D. Biomethane production from various segments of brown seaweed. Energy Conv. Manag. 2018, 174, 855-862. [CrossRef]

135. Monlau, F.; Sambusiti, C.; Barakat, A.; Quéméneur, M.; Trably, E.; Steyer, J.P.; Carrère, H. Do furanic and phenolic compounds of lignocellulosic and algae biomass hydrolyzate inhibit anaerobic mixed cultures? A comprehensive review. Biotechnol. Adv. 2014, 32, 934-951. [CrossRef] 
136. Streefland, M. Algae and Aquatic Biomass for a Sustainable Production of 2nd Generation Biofuels-Deliverable 1.5Report on Biofuel Production Processes from Micro, Macroalgae and Other Aquatic Biomass; AquaFUELs: Brussels, Belgium, 2010.

137. Campbell, P.K.; Beer, T.; Batten, D. Greenhouse Gas Sequestration by Algae-Energy \& Greenhouse Gas Life Cycle Studies. In Proceedings of the 6th Australian Conference on Life Cycle Assessment, Melbourne, Australia, 17-19 February 2009.

138. Gavrilescu, M.; Chisti, Y. Biotechnology-A sustainable alternative for chemical industry. Biotechnol. Adv. 2005, 23, 471-499. [CrossRef]

139. Tamiya, H. Mass Culture of Algae. Annu. Rev. Plant Physiol. 1957, 8, 309-334. [CrossRef]

140. Chisti, Y. Constraints to commercialization of algal fuels. J. Biotechnol. 2013, 167, 201-214. [CrossRef]

141. Harris, P.W.; McCabe, B.K. Review of pre-treatments used in anaerobic digestion and their potential application in high-fat cattle slaughterhouse wastewater. Appl. Energy 2015, 155, 560-575. [CrossRef]

142. Long, J.H.; Aziz, T.N.; Reyes, F.L.d.L.; Ducoste, J.J. Anaerobic co-digestion of fat, oil, and grease (FOG): A review of gas production and process limitations. Process Saf. Environ. Prot. 2012, 90, 231-245. [CrossRef]

143. Jing, H.; Yu, D.; Xia, L.; Yunfei, Z.; Nengmin, Z.; Xiaobo, Y. A Review of Process Limitations and Microbial Community in Anaerobic Digestion of Fat, Oil, and Grease (Fog). Res. Rev. J. Microbiol. Biotechnol. 2016, 5.

144. Dasa, K.T.; Westman, S.Y.; Millati, R.; Cahyanto, M.N.; Taherzadeh, M.J.; Niklasson, C. Inhibitory Effect of Long-Chain Fatty Acids on Biogas Production and the Protective Effect of Membrane Bioreactor. Biomed Res. Int. 2016, 2016, 7263974. [CrossRef]

145. Molina-Alcaide, E.; Carro, M.D.; Roleda, M.Y.; Weisbjerg, M.R.; Lind, V.; Novoa-Garrido, M. In vitro ruminal fermentation and methane production of different seaweed species. Anim. Feed Sci. Technol. 2017, 228, 1-12. [CrossRef]

146. Roy, S.S.; Pal, R. Microalgae in Aquaculture: A Review with Special References to Nutritional Value and Fish Dietetics. Proc. Zool. Soc. 2015, 68, 1-8. [CrossRef]

147. Becker, E.W. Micro-algae as a source of protein. Biotechnol. Adv. 2007, 25, 207-210. [CrossRef]

148. Metcalf, L.; Tchobanoglous, G. Wastewater Engineering: Treatment, Disposal, Reuse (Metcalf $\mathcal{E}$ Eddy); McGraw-Hill: New York, NY, USA, 1972.

149. Rittmann, B.E.; McCarty, P.L. Environmental Biotechnology: Principles and Applications; McGraw-Hill: Singapore, 2001.

150. Tian, H.; Fotidis, I.A.; Mancini, E.; Treu, L.; Mahdy, A.; Ballesteros, M.; González-Fernández, C.; Angelidaki, I. Acclimation to extremely high ammonia levels in continuous biomethanation process and the associated microbial community dynamics. Bioresour. Technol. 2018, 247, 616-623. [CrossRef]

151. Jung, K.A.; Lim, S.R.; Kim, Y.; Park, J.M. Potentials of macroalgae as feedstocks for biorefinery. Bioresour. Technol. 2013, 135, 182-190. [CrossRef] [PubMed]

152. Kostas, E.T.; White, D.A.; Du, C.; Cook, D.J. Selection of yeast strains for bioethanol production from UK seaweeds. J. Appl. Phycol. 2016, 28, 1427-1441. [CrossRef] [PubMed]

153. Anastasakis, K.; Ross, A.B. Hydrothermal liquefaction of the brown macro-alga Laminaria Saccharina: Effect of reaction conditions on product distribution and composition. Bioresour. Technol. 2011, 102, 4876-4883. [CrossRef]

154. Hilton, M.G.; Archer, D.B. Anaerobic digestion of a sulfate-rich molasses wastewater: Inhibition of hydrogen sulfide production. Biotechnol. Bioeng. 1988, 31, 885-888. [CrossRef] [PubMed]

155. Tokusoglu, O.; Unal, M.K. Biomass nutrient profiles of three microalgae: Spirulina platensis, Chlorella vulgaris, and Isochrisis galbana. J. Food Sci. 2003, 68, 1144-1148. [CrossRef]

156. Brown, M.R.; Jeffrey, S.W. The amino acid and gross composition of marine diatoms potentially useful for mariculture. J. Appl. Phycol. 1995, 7, 521-527. [CrossRef]

157. Zeraatkar, A.K.; Ahmadzadeh, H.; Talebi, A.F.; Moheimani, N.R.; McHenry, M.P. Potential use of algae for heavy metal bioremediation, a critical review. J. Environ. Manag. 2016, 181, 817-831. [CrossRef] [PubMed]

158. Besada, V.; Andrade, J.M.; Schultze, F.; Gonzalez, J.J. Heavy metals in edible seaweeds commercialised for human consumption. J. Mar. Syst. 2009, 75, 305-313. [CrossRef]

159. Santos-Ballardo, D.U.; Rossi, S.; Reyes-Moreno, C.; Valdez-Ortiz, A. Microalgae potential as a biogas source: Current status, restraints and future trends. Rev. Environ. Sci. Biotechnol. 2016, 1-22. [CrossRef]

160. Tarchevsky, I.A.; Marchenko, G.N. Cellulose: Biosynthesis and Structure; Springer: Berlin, Germany, 1991.

161. Domozych, D.S. Algal Cell Walls. In eLS; John Wiley \& Sons Ltd.: Chichester, UK, 2011. 
162. Cheng, Y.-S.; Zheng, Y.; Labavitch, J.M.; VanderGheynst, J.S. The impact of cell wall carbohydrate composition on the chitosan flocculation of Chlorella. Process Biochem. 2011, 46, 1927-1933. [CrossRef]

163. Peeler, T.C.; Stephenson, M.B.; Einspahr, K.J.; Thompson, G.A. Lipid characterization of an enriched plasma-membrane fraction of Dunaliella salina grown in media of varying salinity. Plant Physiol. 1989, 89, 970-976. [CrossRef]

164. Ben-Amotz, A.; Polle, J.E.W.; Subba Rao, D.V. The alga Dunaliella: Biodiversity, Physiology, Genomics and Biotechnology; Science Publishers: Enfleld, NJ, USA, 2009.

165. Xu, Y.; Milledge, J.J.; Abubakar, A.; Swamy, R.; Bailey, D.; Harvey, P.J. Effects of centrifugal stress on cell disruption and glycerol leakage from Dunaliella salina. Microalgae Biotechnol. 2015, 1, 20-27. [CrossRef]

166. Wang, J.-K.; Seibert, M. Prospects for commercial production of diatoms. Biotechnol. Biofuels 2017, $10,16$. [CrossRef]

167. Royal Society. Ocean Acidification due to Increasing Atmospheric Carbon Dioxide; Policy Document 12/050; Royal Society: London, UK, 2005.

168. Ganesh Saratale, R.; Kumar, G.; Banu, R.; Xia, A.; Periyasamy, S.; Dattatraya Saratale, G. A critical review on anaerobic digestion of microalgae and macroalgae and co-digestion of biomass for enhanced methane generation. Bioresour. Technol. 2018, 262, 319-332. [CrossRef]

169. Szwaja, S.; Dębowski, M.; Zieliński, M.; Kisielewska, M.; Stańczyk-Mazanek, E.; Sikorska, M. Influence of a light source on microalgae growth and subsequent anaerobic digestion of harvested biomass. Biomass Bioenergy 2016, 91, 243-249. [CrossRef]

170. Fermoso, F.G.; Beltran, C.; Jimenez, A.; Fernandez, M.J.; Rincon, B.; Borja, R.; Jeison, D. Screening of biomethane production potential from dominant microalgae. J. Environ. Sci. Health Part A-Toxic/Hazard. Subst. Environ. Eng. 2016, 51, 1062-1067. [CrossRef]

171. Dixon, C.; Wilken, L.R. Green microalgae biomolecule separations and recovery. Bioresour. Bioprocess. 2018, 5, 14. [CrossRef]

172. Gruber-Brunhumer, M.R.; Jerney, J.; Zohar, E.; Nussbaumer, M.; Hieger, C.; Bromberger, P.; Bochmann, G.; Jirsa, F.; Schagerl, M.; Obbard, J.P.; et al. Associated effects of storage and mechanical pre-treatments of microalgae biomass on biomethane yields in anaerobic digestion. Biomass Bioenergy 2016, 93, 259-268. [CrossRef]

173. Kloareg, B.; Quatrano, R.S. Structure of the cell walls of marine algae and ecophysiological functions of the matrix polysaccharides. Oceanogr. Mar. Biol. 1988, 26, 259-315.

174. Hurd, C.L.; Harrison, P.J.; Bischof, K.; Lobban, C.S. Seaweed Ecology and Physiology, 2nd ed.; Cambridge University Press: Cambridge, UK, 2014.

175. Baldan, B.; Andolfo, P.; Navazio, L.; Tolomio, C.; Mariani, P. Cellulose in algal cell wall: An "in situ" localization. Eur. J. Histochem. 2001, 45, 51-56. [CrossRef] [PubMed]

176. Deniaud-Bouet, E.; Kervarec, N.; Michel, G.; Tonon, T.; Kloareg, B.; Herve, C. Chemical and enzymatic fractionation of cell walls from Fucales: Insights into the structure of the extracellular matrix of brown algae. Ann. Bot. 2014, 114, 1203-1216. [CrossRef] [PubMed]

177. Vanegas, C.H.; Hernon, A.; Bartlett, J. Enzymatic and organic acid pretreatment of seaweed: Effect on reducing sugars production and on biogas inhibition. Int. J. Ambient Energy 2015, 36, 2-7. [CrossRef]

178. Moen, E.; Horn, S.; Østgaard, K. Biological degradation of Ascophyllum nodosum. J. Appl. Phycol. 1997, 9, 347-357. [CrossRef]

179. Berteau, O.; Mulloy, B. Sulfated fucans, fresh perspectives: Structures, functions, and biological properties of sulfated fucans and an overview of enzymes active toward this class of polysaccharide. Glycobiology 2003, 13, 29R-40R. [CrossRef] [PubMed]

180. Rodriguez-Jasso, R.M.; Mussatto, S.I.; Pastrana, L.; Aguilar, C.N.; Teixeira, J.A. Chemical composition and antioxidant activity of sulphated polysaccharides extracted from Fucus vesiculosus using different hydrothermal processes. Chem. Pap. 2014, 68, 203-209. [CrossRef]

181. Robic, A.; Sassi, J.-F.; Dion, P.; Lerat, Y.; Lahaye, M. Seasonal variability of physicochemical and rheological properties of ulvan in two Ulva species (Chlorophyta) from the Brittany coast 1. J. Phycol. 2009, 45, 962-973. [CrossRef] [PubMed]

182. Savithramma, N.; Linga Rao, M.; Venkateswarlu, P. Isolation and Identification of Phenolic Compounds from Boswellia ovalifoliolata Bal. \& Henry and Their Free Radical Scavenger Activity. Int. J. Drug Deliv. Technol. 2014, 4, 14-21. 
183. Pérez, M.J.; Falqué, E.; Domínguez, H. Antimicrobial Action of Compounds from Marine Seaweed. Mar. Drugs 2016, 14, 52. [CrossRef]

184. Holdt, S.; Kraan, S. Bioactive compounds in seaweed: Functional food applications and legislation. J. Appl. Phycol. 2011, 23, 543-597. [CrossRef]

185. Glombitza, K.W.; Forster, M.; Farnham, W.F. Antibiotics from algae. 25. Polyhydroxyphenyl ethers from the brown alga Sargassum muticum (yendo) fensholt. Bot. Mar. 1982, 25, 449-453. [CrossRef]

186. Montero, L.; Sanchez-Camargo, A.P.; Garcia-Canas, V.; Tanniou, A.; Stiger-Pouvreau, V.; Russo, M.; Rastrelli, L.; Cifuentes, A.; Herrero, M.; Ibanez, E. Anti-proliferative activity and chemical characterization by comprehensive two-dimensional liquid chromatography coupled to mass spectrometry of phlorotannins from the brown macroalga Sargassum muticum collected on North-Atlantic coasts. J. Chromatogr. A 2016, 1428, 115-125. [CrossRef] [PubMed]

187. Moorthi, P.V.; Balasubramanian, C. Antimicrobial properties of marine seaweed, Sargassum muticum against human pathogens. J. Coast. Life Med. 2015, 3, 122-125. [CrossRef]

188. Lordan, S.; Smyth, T.J.; Soler-Vila, A.; Stanton, C.; Ross, R.P. The $\alpha$-amylase and $\alpha$-glucosidase inhibitory effects of Irish seaweed extracts. Food Chem. 2013, 141, 2170-2176. [CrossRef] [PubMed]

189. Dai, X.; Li, X.; Zhang, D.; Chen, Y.; Dai, L. Simultaneous enhancement of methane production and methane content in biogas from waste activated sludge and perennial ryegrass anaerobic co-digestion: The effects of pH and C/N ratio. Bioresour. Technol. 2016, 216, 323-330. [CrossRef] [PubMed]

190. Tanniou, A.; Vandanjon, L.; Incera, M.; Leon, E.S.; Husa, V.; Le Grand, J.; Nicolas, J.L.; Poupart, N.; Kervarec, N.; Engelen, A.; et al. Assessment of the spatial variability of phenolic contents and associated bioactivities in the invasive alga Sargassum muticum sampled along its European range from Norway to Portugal. J. Appl. Phycol. 2014, 26, 1215-1230. [CrossRef]

191. Tabassum, M.R.; Xia, A.; Murphy, J.D. Seasonal variation of chemical composition and biomethane production from the brown seaweed Ascophyllum nodosum. Bioresour. Technol. 2016, 216, 219-226. [CrossRef]

192. Milledge, J.J.; Nielsen, B.V.; Harvey, P.J. The inhibition of anaerobic digestion by model phenolic compounds representative of those from Sargassum muticum. J. Appl. Phycol. 2018. [CrossRef]

193. Hierholtzer, A.; Akunna, J.C. Modelling sodium inhibition on the anaerobic digestion process. Water Sci. Technol. 2012, 66, 1565-1573. [CrossRef]

194. Lefebvre, O.; Moletta, R. Treatment of organic pollution in industrial saline wastewater: A literature review. Water Res. 2006, 40, 3671-3682. [CrossRef] [PubMed]

195. Zhang, Y.; Alam, M.A.; Kong, X.; Wang, Z.; Li, L.; Sun, Y.; Yuan, Z. Effect of salinity on the microbial community and performance on anaerobic digestion of marine macroalgae. J. Chem. Technol. Biotechnol. 2017, 92, 2392-2399. [CrossRef]

196. Chen, Y.; Cheng, J.J.; Creamer, K.S. Inhibition of anaerobic digestion process: A review. Bioresour. Technol. 2008, 99, 4044-4064. [CrossRef]

197. Chen, W.H.; Han, S.K.; Sung, S. Sodium inhibition of thermophilic methanogens. J. Environ. Eng. 2003, 129, 506-512. [CrossRef]

198. Ramakrishnan, B.; Kumaraswamy, S.; Mallick, K.; Adhya, T.K.; Rao, V.R.; Sethunathan, N. Effect of various anionic species on net methane production in flooded rice soils. World J. Microbiol. Biotechnol. 1998, 14, 743-749. [CrossRef]

199. El-Dessouky, H.T.; Ettouney, H.M. Fundamentals of Salt Water Desalination; Elsevier: Amsterdam, The Nertherlands, 2002.

200. Nikolaison, L.; Dahl, J.; Bech, K.S.; Bruhn, A.; Rasmussen, M.B.; Bjerre, A.B.; Nielsen, H.B.; Ambus, P.; Rost, K.A.; Kadar, Z.; et al. Energy Production from Macroalgae. In Proceedings of the 20th European Biomass Conference, Milan, Italy, 18-22 June 2012.

201. Adams, J.M.M.; Schmidt, A.; Gallagher, J.A. The impact of sample preparation of the macroalgae Laminaria digitata on the production of the biofuels bioethanol and biomethane. J. Appl. Phycol. 2015, 27, 985-991. [CrossRef]

202. Milledge, J.; Nielsen, B.; Sadek, M.; Harvey, P. Effect of Freshwater Washing Pretreatment on Sargassum muticum as a Feedstock for Biogas Production. Energies 2018, 11, 1771. [CrossRef]

203. Roberts, K.P.; Heaven, S.; Banks, C.J. Quantification of methane losses from the acclimatisation of anaerobic digestion to marine salt concentrations. Renew. Energy 2016, 86, 497-506. [CrossRef] 
204. Marquez, G.P.B.; Reichardt, W.T.; Azanza, R.V.; Onda, D.F.L.; Lluisma, A.O.; Montaño, M.N.E.J.W.; Valorization, B. Dominance of Hydrogenotrophic Methanogens at the Peak of Biogas Production in Thalassic Digesters. Waste Biomass Valoriz. 2015, 6, 201-207. [CrossRef]

205. Jard, G.; Jackowiak, D.; Carrère, H.; Delgenes, J.P.; Torrijos, M.; Steyer, J.P.; Dumas, C. Batch and semi-continuous anaerobic digestion of Palmaria palmata: Comparison with Saccharina latissima and inhibition studies. Chem. Eng. J. 2012, 209, 513-519. [CrossRef]

206. Sudmalis, D.; Millah, S.K.; Gagliano, M.C.; Butré, C.I.; Plugge, C.M.; Rijnaarts, H.H.M.; Zeeman, G.; Temmink, H. The potential of osmolytes and their precursors to alleviate osmotic stress of anaerobic granular sludge. Water Res. 2018, 147, 142-151. [CrossRef]

207. Vyrides, I.; Stuckey, D.C. Compatible solute addition to biological systems treating waste/wastewater to counteract osmotic and other environmental stresses: A review. Crit. Rev. Biotechnol. 2017, 37, 865-879. [CrossRef] [PubMed]

208. Gao, Y.; Fang, Z.; Liang, P.; Zhang, X.; Qiu, Y.; Kimura, K.; Huang, X. Anaerobic digestion performance of concentrated municipal sewage by forward osmosis membrane: Focus on the impact of salt and ammonia nitrogen. Bioresour. Technol. 2019, 276, 204-210. [CrossRef]

209. Wang, X.; Lu, X.; Li, F.; Yang, G. Effects of Temperature and Carbon-Nitrogen (C/N) Ratio on the Performance of Anaerobic Co-Digestion of Dairy Manure, Chicken Manure and Rice Straw: Focusing on Ammonia Inhibition. PLoS ONE 2014, 9, e97265. [CrossRef] [PubMed]

210. Puyuelo, B.; Ponsá, S.; Gea, T.; Sánchez, A. Determining C/N ratios for typical organic wastes using biodegradable fractions. Chemosphere 2011, 85, 653-659. [CrossRef] [PubMed]

211. Persson, S.P.E.; Bartlett, H.D.; Branding, A.E.; Regan, R.W. Agricultural Anaerobic Digesters; Pennsylvania State University: Pennsylvania, PA, USA, 1979.

212. Peu, P.; Picard, S.; Diara, A.; Girault, R.; Béline, F.; Bridoux, G.; Dabert, P. Prediction of hydrogen sulphide production during anaerobic digestion of organic substrates. Bioresour. Technol. 2012, 121, 419-424. [CrossRef] [PubMed]

213. Baird, M.E.; Middleton, J.H. On relating physical limits to the carbon: Nitrogen ratio of unicellular algae and benthic plants. J. Mar. Syst. 2004, 49, 169-175. [CrossRef]

214. Wernberg, T.; Thomsen, M.S.; Staehr, P.A.; Pedersen, M.F. Comparative phenology of Sargassum muticum and Halidrys siliquosa (Phaeophyceae: Fucales) in Limfjorden, Denmark. Bot. Mar. 2001, 44, 31-39. [CrossRef]

215. Lapointe, B.E.; West, L.E.; Sutton, T.T.; Hu, C. Ryther revisited: Nutrient excretions by fishes enhance productivity of pelagic Sargassum in the western North Atlantic Ocean. J. Exp. Mar. Biol. Ecol. 2014, 458, 46-56. [CrossRef]

216. Oyesiku, O.O.; Egunyomi, A. Identification and chemical studies of pelagic masses of Sargassum natans (Linnaeus) Gaillon and S. fluitans (Borgessen) Borgesen (brown algae), found offshore in Ondo State, Nigeria. Afr. J. Biotechnol. 2014, 13, 1188-1193. [CrossRef]

217. Wang, S.; Wang, Q.; Jiang, X.M.; Han, X.X.; Ji, H.S. Compositional analysis of bio-oil derived from pyrolysis of seaweed. Energy Conv. Manag. 2013, 68, 273-280. [CrossRef]

218. Jankowska, E.; Sahu, A.K.; Oleskowicz-Popiel, P. Biogas from microalgae: Review on microalgae's cultivation, harvesting and pretreatment for anaerobic digestion. Renew. Sustain. Energy Rev. 2017, 75, 692-709. [CrossRef]

219. Solé-Bundó, M.; Garfí, M.; Matamoros, V.; Ferrer, I. Co-digestion of microalgae and primary sludge: Effect on biogas production and microcontaminants removal. Sci. Total Environ. 2019. [CrossRef] [PubMed]

220. Oliveira, J.V.; Alves, M.M.; Costa, J.C. Optimization of biogas production from Sargassum sp. using a design of experiments to assess the co-digestion with glycerol and waste frying oil. Bioresour. Technol. 2015, 175, 480-485. [CrossRef] [PubMed]

221. Angelidaki, I.; Karakashev, D.; Alvarado-Morales, M. Anaerobic Co-Digestion of Cast Seaweed and Organic Residues; Technical University of Denmark: Lyngby, Denmark, 2017.

(C) 2019 by the authors. Licensee MDPI, Basel, Switzerland. This article is an open access article distributed under the terms and conditions of the Creative Commons Attribution (CC BY) license (http:/ / creativecommons.org/licenses/by/4.0/). 